Policy Research Working Paper 2717

Bridging the Economic Divide within Nations
A Scorecard on the Performance of Regional Development Policies in Reducing Regional Income Disparities
What is the record of policies aimed at reducing income disparities among regions within countries?

Paradoxically, creating a level playing field helps disadvantaged regions more than do paternalistic protectionist policies.

Raja Shankar

Anwar Shah

The World Bank

Operations Evaluation Department

Country Evaluation and Regional Relations Division

November 2001 
Policy Research Working Paper 2717

\section{Summary findings}

Regional inequalities represent a continuing development challenge in most countries, especially those with large geographic areas. Globalization heightens these challenges because it places a premium on skills: since rich regions typically also have better educated and better skilled labor, the gulf between rich and poor regions widens.

While central governments in unitary states are relatively unconstrained in their choice of policies for reducing regional disparities, in a federation the division of powers curtails federal flexibility in policy choice. Thus in federal states large regional disparities can represent serious threats, with the state's inability to deal with such inequities creating potential for disunity and, in extreme cases, for disintegration. Inequalities beyond a threshold may lead to calls for separation by both the richest and the poorest regions. While the poorest regions may consider the inequalities a manifestation of regional injustice, the richest regions may view the union with the poorest regions as holding them back in their drive toward prosperity.

Under these circumstances, there is a presumption in development economics that decentralized fiscal arrangements would lead to ever widening regional inequalities. Shankar and Shah provide an empirical test of this hypothesis.

The authors conclude that regional development policies have failed in almost all countries, federal and unitary alike. Among 10 countries with high or substantial regional income inequality, only one (Thailand) has experienced convergence in regional incomes. Still, federal countries do better in restraining regional inequalities, because of the greater political risk these disparities pose for such countries.

The authors classify countries by degree of convergence in regional incomes:

- Countries experiencing regional income divergenceBrazil, China, India, Indonesia, the Philippine:, Romania, the Russian Federation, Sri Lanka, and Vietna m.

- Countries experiencing no significant change in regional income variation - Canada and Mexico.

- Countries experiencing regional income convergence-Chile, Pakistan, Thailand, the United States, and Uzbekistan.

Regional development outcomes observed in these countries provide a revealing look at the impart of regional development policies. While countrie; experiencing divergence tend to focus on interventionist policies, those experiencing convergence have taken a hands-off approach to regional development and instead focused on promoting an economic union by removing barriers to factor mobility and ensuring minimum standards in basic services across the nation. In Chile, for example, convergence in regional incomes is largely attributable to liberalizing the economy and re noving distortions so that regions could discover their own comparative advantage. In Pakistan and the Urited States convergence is attributable to greater factor mojility. Paradoxically, creating a level playing field helos disadvantaged regions more than do paternalis-ic protectionist policies.

This paper-a product of the Country Evaluation and Regional Relations Division, Operations Evaluation Defartmentis part of a larger effort in the department to evaluate decentralization programs and policies. Copies of the paper are available free from the World Bank, $1818 \mathrm{H}$ Street NW, Washington, DC 20433. Please contact Agnes Santos, room H3306, telephone 202-473-1675, fax 202-522-3124, email address asantos $a$ worldbank.org. Policy Research Working Papers are also posted on the Web at http://econ.worldbank.org. The authors may be contacted at raja(t nit.edu or ashah $\widehat{a}$ worldbank.org. November 2001. (54 pages)

The Policy Research Working Paper Series disseminates the findings of work in progress to encourage the exchange of ideas about development issues. An objective of the series is to get the findings out quickly, even if the presentations are less than fully polished. The papers carry the names of the authors and should be cited accordingly. The findings, interpretations, and conclusions expressed in: this paper are entirely those of the authors. They do not necessarily represent the view of the World Bank, its Executive Directors, or the countries they represent.

Produced by the Policy Research Dissemination Center 


\title{
Bridging the economic divide within nations: A scorecard on the performance of regional development policies in reducing regional income disparities
}

\author{
By Raja Shankar and Anwar Shah ${ }^{1}$
}

\section{Introduction}

Regional inequalities represent an ever present development challenge in most countries especially those with large geographic areas under their jurisdictions. Globalization heightens these challenges as it places a premium on skills. With globalization skills rather than the resource base of regions determine their competitiveness. Skilled workers gain at the expense of unskilled ones. As typically rich regions also have better educated and better skilled labor, the gulf between rich and poor regions widens. Large regional disparities represent serious threats in federal states as the inability of the state to deal with such inequities creates potential for disunity and, in extreme cases, for disintegration. While the policy challenges in reducing regional disparities are large, federal flexibility in the choice of instruments is curtailed by the division of powers in a federation. Central governments in unitary states are, on the other hand, relatively unconstrained in their choice of appropriate policies and instruments. Under these circumstances, there is a presumption in development economics that a decentralized fiscal constitution would lead to ever widening regional inequalities. This paper attempts to provide an empirical test of this hypothesis .

\footnotetext{
${ }^{1}$ The authors are grateful to Homi Kharas, Peter Fallon and members of the Decentralization and Subnational Thematic Groups for comments. Please address comments to: ashah@worldbank.org
} 
The paper is organized as follows. Section 2 provides an introductory overview cf various measures of regional inequality that are available from the literature. Section 3 provides estimation of inequality measures for a sample of 8 industrial $^{1}$ and 18 developing countries. These countries are further sub-grouped in federal and unitary countries for analytical purposes. For a smaller sub-set of 14 countries, Section 4 presents evidence on historical trends in regional disparities in per capita income. Section 5 provides a summary scorecard on national pclicies for regional development.

\section{Measures of regional inequality}

Interest in income inequality has led to the development of several ways of measuring it. Two types of measures are of interest in this paper - static and dynamic. Static measures provide a snapshot of these inequalities at a point of time whereas the dynamic measures capture historical trends. These are described below in turn.

\section{(a) Static measures of regional inequality}

The measurement of regional disparities is an ardous task and no single statistical measure is able to capture its myriad dimensions. Recognizing these difficulties, this paper has applied a variety of measures to highlight various dimensions of these inequalities. The selected measures are briefly described in the following paragraphs.

\section{Maximum to minimum ratio [MMR]}

A comparison of the per capita GRDP (gross regional domestic product) of the region with the highest income to the region with the lowest income (minimum per capita GRDP) provides a measure of the range of these disparities. If this measure is small (close to 1), then it would mean that the different regions have relatively equal incomes. If this measure is large, then the 
interpretation is more problematic, as it does not tell us if the high ratio is due to substantial variation in the distribution of per capita GDRPs or the presence of outliers. Nevertheless, MMR provides a quick, easy to comprehend and politically powerful measure of regional income inequality.

\section{Coefficient of variation [CV]}

The coefficient of variation is one of the most widely used measures of regional inequality in the literature. ${ }^{2}$ The $\mathrm{CV}$ is a measure of dispersion around the mean. This dispersion can be calculated in a few different ways. Several authors have used the standard deviation of the logarithm of real per capita GRDP. ${ }^{3}$ In this study, however, the CV as defined below attempts to capture the dispersion of per capita GRDP. This measure is standardized and can be used to make comparisons between countries and over time (especially if GRDP data is only available in current prices). In the following analysis, the CV is calculated in two ways. The first, the "simple coefficient of variation" is an unweighted measure as given below:

$$
C V_{U}=\frac{\sqrt{\sum_{i} \frac{\left(y_{i}-\bar{y}_{U}\right)^{2}}{N}}}{\bar{y}_{U}}
$$

where $y_{i}$ is the income per capita of state $\mathrm{i}, \mathrm{N}$ is the number of regions and $\bar{y}_{U}$ is the mean per capita GRDP. $\bar{y}_{U}$ is computed as the mean of the regional incomes per capita without weighting them by population as follows:

$$
\bar{y}_{U}=\frac{1}{N} \sum_{i} y_{i}
$$

This is slightly different from Williamson's $(1965,11)$ formula for the unweighted CV, where the mean income, $\bar{y}$, is taken as the national mean per capita GRDP. The Williamson measure 
is not appropriate in this application as it uses a weighted measure for the denominator and an un-weighted one for the numerator. $\mathrm{CV}_{U}$ varies from 0 for perfect inequality (equal per capita GRDP for the different regions) to $\sqrt{N-1}$ for perfect inequality (only one region has all the GDP). Although this measure can be used for comparisons of regional disparities in countries across time, it is problematic for comparisons between countries because the inequality value is sensitive to the number of regions.

This problem is somewhat overcome by the "weighted coefficient of variation", where each regional deviation is weighted by its share in the national population. This measure is calculated as given below:

$$
C V_{W}=\frac{\sqrt{\sum_{i}\left(y_{i}-\bar{y}\right)^{2} \frac{p_{i}}{P}}}{\bar{y}}
$$

$y_{i}$ is the income per capita of region $\mathrm{i}$, and $\bar{y}$ is the national mean per capita GDP. P is the national population and $p_{i}$ is the population of state i. $C V_{w}$ varies from 0 for perfect equality to $\sqrt{\frac{P-p_{i}}{p_{i}}}$ for perfect inequality where region i has all the GDP. This is better than $C V_{U}$ for cross country comparison as the measure of inequality depends not on the number of regions but on the population proportion of the regions.

\section{Relative mean deviation $\left[R_{w}\right]$}

Following Williamson $(1965,16)$ and Kakwani $(1980,79)$ we also compute the relative mean deviation of per capita GRDP as follows: 


$$
R_{w}=\frac{\sum_{i}\left|y_{i}-\bar{y}\right| \frac{p_{i}}{P}}{\bar{y}}
$$

$y_{i}$ is the income per capita of region $\mathrm{i}$, and $\bar{y}$ is the national mean income per capita. $\mathrm{P}$ is the national population and $p_{i}$ is the population of state i. $R_{w}$ is a measure weighted by population proportions of the regions. As CV is computed by squaring differences, it could be unnecessarily sensitive to outliers. $R_{w}$, which avoids this problem can thus be used to check the $\mathrm{CV}$ results. $R_{w}$ varies from 0 for perfect equality to 2 for perfect inequality. Kakwani (1980) divides $R_{w}$ by 2 to get his measure of relative mean deviation, as it gives the desirable property of the measure becoming equal to 1 for perfect inequality. However, as we use $R_{w}$ only to check our $\mathrm{CV}$ results for outlier effects, we do not follow Kakwani (1980) in this regard.

\section{Gini index [G]}

The Gini index like the coefficient of variation is widely used in the inequality literature. ${ }^{4}$ Following Kakwani (1980), we compute the unweighted Gini index as follows:

$$
G_{U}=\left(\frac{1}{2 \bar{y}_{U}}\right) \frac{1}{n(n-1)} \sum_{i}^{n} \sum_{j}^{n}\left|y_{i}-y_{j}\right|
$$

$y_{i}$ and $y_{j}$ are the incomes per capita of region $\mathrm{i}$ and $\mathrm{j}$ respectively. $\mathrm{n}$ is the number of regions, and $\bar{y}_{U}$ is the unweighted mean of the per capita GRDPs. $G_{U}$ varies from 0 for perfect equality to 1 for perfect inequality. The Gini index thus measured is the arithmetic average of $\mathrm{n}(\mathrm{n}-1)$ differences of per capita GRDPs, taken as absolute values divided by the maximum possible value of this average, $2 \bar{y}_{U}$. 
The weighted Gini index, which weights each difference of per capita GRDPs by respective population proportions is calculated as shown below:

$$
G_{W}=\left(\frac{1}{2 \bar{y}}\right) \sum_{i}^{n} \sum_{j}^{n}\left|y_{i}-y_{j}\right| \frac{p_{i} p_{j}}{P^{2}}
$$

$\bar{y}$ is the national mean per capita GDP. $p_{i}$ and $p_{j}$ are the populations of regions $i$ and $j$ respectively. $\mathrm{P}$ is the national population, and $\mathrm{n}$ the number of regions. $G_{W}$ varies from 0 for

perfect equality to $1-\frac{p_{i}}{P}$ for perfect inequality. If $p_{i}$ is small compared to $\mathrm{P}$, i.e., if the region with a small proportion of the population produced all the GDP then the value for perfect inequality would approach 1 .

\section{Theil index $[\mathrm{T}]$}

A final measure of inequality used in this paper is an information or entropy measure of inequality. Following Theil (1967), it is computed as follows:

$$
T=\sum_{i} x_{i} \log \left(\frac{x_{i}}{q_{i}}\right)
$$

$x_{i}$ is the GDP share of region $\mathrm{i}$ of region $\mathrm{i}$ and $q_{i}$ is the population share of region $\mathrm{i}$. For equal per capita GRDPs, i.e., with GRDPs proportional to regional populations, $\mathrm{T}$ takes a value of 0. For a case where region $i$ gets all the income, $\mathrm{T}$ becomes $\log \frac{P}{p_{i}}$, where $\mathrm{P}$ is total population of the country, and $p_{i}$ is the population of state $i$. Note here that as the population share of region $\mathrm{i}$ goes down, $\mathrm{T}$ rises if region $\mathrm{i}$ gets all the income.

\section{(b) Dynamic Concepts of Regional Inequality}


While a snapshot view of regional income disparities is illuminating, a longer term perspective is more helpful in ascertaining the impact of public policies. This requires developing a time profile of static measures and discerning whether or not these inequalities appear to diminish (the socalled convergence hypothesis) or accentuate (divergence hypothesis) over time. Strong convergence hypothesis suggests that equality in factor productivity and income levels will be achieved regardless of initial conditions provided diffusion and adoption of technological change is unrestrained. A weak convergence hypothesis on the other hand requires competitive market structures to send the right signals for allocation of productive factors (see Boldrin, 2000). Under the weak convergence hypothesis, differences in technology alone do not explain the differences in factor productivity. Lack of competitive price signals such as those observed with regional incentives and subsidies, infant industry protection, barriers to trade etc. may perpetuate regional differences in factor productivity and income.

At the conceptual level regional convergence is assured under perfect competition, constant returns to scale with no external effects and free and cost-less mobility of factors across relatively homogeneous (with respect to resource endowment, topography, composition of population, human capital, political and legal environment, informal culture, etc.) regions within the nation state. This requires that political units are commensurate with reasonably large geographic areas with reasonably diverse endowments so that regional income differentials are attributable to policy and institutional considerations rather than simply to an irreversible acts of nature. For example one should not expect to have convergence among three completely heterogeneous regions comprising solely desert, mountainous and arable lands.

Regional convergence becomes more difficult to achieve under increasing returns to scale and with externalities of investment and growth. Strong non-convergence (divergence) hypothesis places a greater emphasis on path dependency (initial conditions matter), increasing returns to 
scale, and externalities of investment as sources of differences in factor productivity and growth (see Krugman 1991, Romer, 1990). Realization of increasing returns to scale and/or agglomeration economies under perfect mobility in one of the regions and not others would accentuate regional divergence. Divergence would also happen if factors are either unable (due to impediments) or unwilling ( say age and ethnicity consideration) to move. Under strong divergence hypothesis, inequality in levels of income and resource endowments will prevent convergence in regional growth rates. Under a weak divergence hypothesis attainment of a minimum threshold of physical and knowledge capital in the leading regions are necesscry for persistence in the divergence of growth paths. Thus some regions that attain the minimum thresholds in these factors may form "clubs" or "growth poles" and may grow faster than others and achieve "club convergence". Public policies to break this regional concentration of powers may have tradeoffs between national growth and overcoming regional inequalities (for a discussion of this issue in the European Union context, please see Boldrin, 2000). In federal countries regional inequalities are likely to be given significant importance in evaluating any trade-offs that may be observed. Secion 4 provides empirical evidence on the outcome of the choices on these tradeoffs that are made in various countries.

Two statistical concepts are helpful in looking at the dynamics of regional inequalities. First, a reduction in the dispersion of regional income over time is termed as sigma convergence. Second, any catching up in incomes by relatively poorer regions through faster growth is called beta convergence (see Barro and Sala-i-Martin, 1995, p.383). Section 4 provides empirical estimates on sigma convergence for 16 countries and on beta convergence for 8 countries. 


\section{Regional disparities - a cross-country snapshot}

The data on regional incomes is available only for a surprisingly small number of developing countries. We could find such data for 8 industrial and 17 developing countries. In the following, measures of regional income inequality are presented separately for industrial and non-industrial countries. The experiences of federal and unitary countries are also compared.

\subsection{Industrial countries}

Table 3.1 presents our calculations of the different measures of regional inequality of per capita GRDP in seven industrial countries - four federal and three unitary. For Germany, the inequality measures are presented for the unified Germany as well as for the states of former West Germany. As expected, former West Germany is less unequal than unified Germany. 
Table 3.1: Regional disparities within industrial countries

\begin{tabular}{|c|c|c|c|c|c|c|c|c|}
\hline Country & Year & $\begin{array}{l}\text { Max/Min } \\
\text { (MMR) }\end{array}$ & $\begin{array}{l}\text { Simple } \\
\text { coefficient } \\
\text { of variation } \\
(\mathrm{CVu})\end{array}$ & $\begin{array}{l}\text { Weighted } \\
\text { coefficient } \\
\text { of variation } \\
(\mathrm{CV} \text { w })\end{array}$ & $\begin{array}{l}\text { Relative } \\
\text { mean } \\
\text { Deviation } \\
(\mathrm{Rw})\end{array}$ & $\begin{array}{l}\text { Unweight } \\
\text { ed gini } \\
\text { index } \\
(\mathrm{Gu})\end{array}$ & $\begin{array}{l}\text { Weighted } \\
\text { gini index } \\
(\mathrm{Gw})\end{array}$ & Theil index $(T)$ \\
\hline \multicolumn{9}{|l|}{ Federal } \\
\hline \multirow[t]{2}{*}{ Canada } & 1997 & 1.838 & 0.201 & 0.137 & 0.123 & 0.118 & 0.067 & 0.008 \\
\hline & 1998 & 1.718 & 0.195 & 0.137 & 0.127 & 0.113 & 0.068 & 0.006 \\
\hline United States & 1997 & 1.927 & 0.162 & 0.122 & 0.097 & 0.090 & 0.039 & 0.007 \\
\hline Germany & 1995-97 & 3.048 & 0.341 & 0.262 & 0.197 & 0.191 & 0.122 & 0.027 \\
\hline $\begin{array}{l}\text { Former West } \\
\text { Germany }\end{array}$ & $1995-97$ & 2.033 & 0.241 & 0.207 & 0.140 & 0.128 & 0.076 & 0.010 \\
\hline Spain & 1995-97 & 1.866 & 0.189 & 0.210 & 0.189 & 0.111 & 0.118 & 0.022 \\
\hline \multicolumn{9}{|l|}{ Unitary } \\
\hline France & 1995-97 & 2.039 & 0.178 & 0.267 & 0.206 & 0.096 & 0.126 & 0.032 \\
\hline Italy & |1995-97 & 2.228 & 0.262 & 0.264 & 0.243 & 0.152 & 0.145 & 0.037 \\
\hline $\begin{array}{l}\text { United } \\
\text { Kingdom }\end{array}$ & 1995-97 & 1.794 & 0.177 & 0.178 & 0.123 & 0.085 & 0.083 & 0.015 \\
\hline
\end{tabular}


By most measures of inequality, the federal countries have lower levels of regional disparity than the unitary countries in our sample. This is especially true for the population weighted measures, which are more appropriate for cross country comparisons. Figure 1 shows the weighted measures of regional inequality for developed countries. The figure is ordered in descending order of the weighted CV. Except for the UK, the federal countries in our sample have lower values for all the inequality measures.

Figure 3.1: Regional disparities within industrial countries

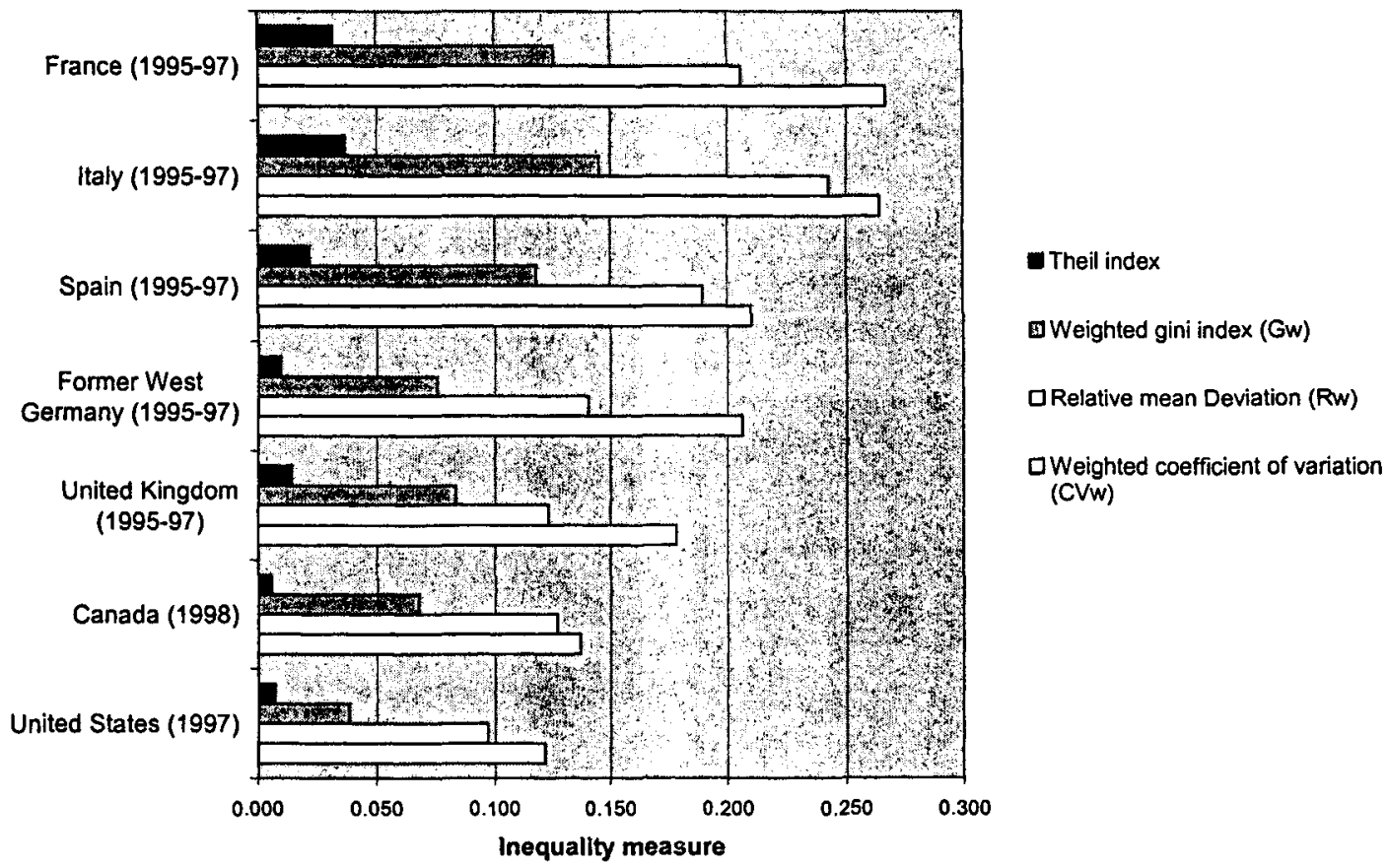

Canada and the United States have the lowest levels of inequality on almost all measures. Further the weighted values are smaller than unweighted ones, showing that the provinces or states with extreme per capita GRDPs are generally those with smaller populations. They are followed by the United Kingdom, and then former West Germany and Spain. France and Italy have the highest regional disparities. The weighted and unweighted values of inequality for the UK and Italy are similar, showing that regions at different points of the income distribution have similar 
populations. As expected, unified Germany is more unequal than just the states of former West Germany. The weighted values are lower as in the case of Canada and the US. Spain and France's weighted inequality measures are higher than the unweighted ones. This means that regions with extreme per capita GRDPs have larger populations in these countries. The relative mean deviation, which we use to check for a few extreme deviations, is significantly different only for the United Kingdom and former West Germany.

\subsection{Non-industrial countries}

Table 3.2 presents our calculations of the different measures of regional inequality in 18 developing countries -5 federal and 13 unitary. In general, on all the measures of inequality, the developing countries are much more unequal than the developed countries. Except for Pakistan and Romania, all the developing countries are more unequal than the most unequal developed country in our sample, Italy. On average, if one takes the weighted $\mathrm{CV}$, developing countries are two to six times more unequal than the developed countries. 
Table 3.2: Regional disparities within non-industrial countries

\begin{tabular}{|c|c|c|c|c|c|c|c|c|}
\hline Country & Year & $\begin{array}{l}\text { Max/Min } \\
\text { (MMR) }\end{array}$ & $\begin{array}{l}\text { Simple } \\
\text { coefficient } \\
\text { of variation } \\
\text { (CVu) }\end{array}$ & $\begin{array}{l}\text { Weighted } \\
\text { coefficient } \\
\text { of variation } \\
(C \vee w)\end{array}$ & $\begin{array}{l}\text { Relative } \\
\text { mean } \\
\text { Deviation } \\
(R w) \\
\end{array}$ & $\begin{array}{l}\text { Unweight } \\
\text { ed gini } \\
\text { index } \\
(\mathrm{Gu}) \\
\end{array}$ & $\begin{array}{l}\text { Weighted } \\
\text { gini index } \\
(G w) \\
\end{array}$ & Theil index $(T)$ \\
\hline \multicolumn{9}{|l|}{ Federal } \\
\hline Brazil & 1997 & 7.567 & 0.563 & 0.468 & 0.409 & 0.334 & 0.267 & 0.116 \\
\hline India & 1997 & 3.811 & 0.387 & 0.414 & 0.334 & 0.226 & 0.227 & 0.082 \\
\hline \multirow[t]{2}{*}{ Mexico } & 1997 & 5.793 & 0.473 & 0.571 & 0.422 & 0.253 & 0.301 & 0.136 \\
\hline & 1998 & 5.874 & 0.469 & 0.566 & 0.421 & 0.251 & 0.300 & 0.134 \\
\hline \multirow[t]{2}{*}{ Pakistan } & 1997 & 1.514 & 0.186 & 0.150 & 0.094 & 0.113 & 0.072 & 0.009 \\
\hline & 1998 & 1.516 & 0.183 & 0.141 & 0.095 & 0.114 & 0.069 & 0.008 \\
\hline Russia & 1997 & 21.307 & 0.625 & 0.645 & 0.387 & 0.283 & 0.280 & 0.153 \\
\hline \multicolumn{9}{|l|}{ Unitary } \\
\hline Chile & 1994 & 5.696 & 0.486 & 0.334 & 0.243 & 0.267 & 0.165 & 0.052 \\
\hline \multirow[t]{3}{*}{ China } & 1997 & 11.625 & 0.692 & 0.924 & 0.666 & 0.351 & 0.250 & 0.111 \\
\hline & 1998 & 12.183 & 0.709 & 0.952 & 0.679 & 0.357 & 0.254 & 0.115 \\
\hline & 1999 & 12.507 & 0.730 & 0.987 & 0.694 & 0.365 & 0.264 & 0.125 \\
\hline \multirow[t]{2}{*}{ Indonesia } & 1997 & 11.048 & 0.827 & 0.716 & 0.401 & 0.378 & 0.274 & 0.176 \\
\hline & 1998 & 11.436 & 0.832 & 0.722 & 0.416 & 0.381 & 0.277 & 0.178 \\
\hline Nepal & 1996 & 1.440 & 0.157 & & & & & \\
\hline \multirow[t]{2}{*}{ Philippines } & 1997 & 6.653 & 0.530 & 0.532 & 0.367 & 0.307 & 0.261 & 0.123 \\
\hline & 1998 & 6.760 & 0.536 & 0.537 & 0.369 & 0.311 & 0.262 & 0.125 \\
\hline Poland & 1996 & 2.031 & 0.206 & & & & & \\
\hline Romania & 1996 & 1.783 & 0.189 & 0.174 & 0.132 & 0.106 & 0.090 & 0.012 \\
\hline Sri Lanka & 1995 & 3.362 & 0.394 & 0.452 & 0.397 & 0.230 & 0.249 & 0.101 \\
\hline South Africa & 1994 & 7.038 & 0.621 & 0.639 & 0.558 & 0.352 & 0.341 & 0.195 \\
\hline Thailand & 1997 & 8.273 & 0.797 & 0.925 & 0.745 & 0.438 & 0.442 & 0.351 \\
\hline Uganda & 1997-98 & 1.760 & 0.274 & & & & & \\
\hline \multirow[t]{3}{*}{ Uzbekistan } & \begin{tabular}{|l|}
1997 \\
\end{tabular} & 3.047 & 0.353 & 0.355 & 0.238 & 0.155 & 0.170 & 0.054 \\
\hline & 1998 & 2.991 & 0.321 & 0.320 & 0.218 & 0.147 & 0.159 & 0.046 \\
\hline & 1999 & 2.779 & 0.304 & 0.301 & 0.206 & 0.142 & 0.152 & 0.041 \\
\hline Vietnam & 1997 & 24.746 & 1.067 & 0.996 & 0.596 & 0.372 & 0.410 & 0.306 \\
\hline
\end{tabular}


As in the case of developed countries, unitary developing countries are, in general, more unequal than federal developing countries. Figure 3.2 presents the weighted measures of inequality for developing countries for 1997 or the latest available year before 1997. The countries are presented in descending order of the weighted $\mathrm{CV}$. The countries with the highest measures of inequality are large unitary countries - Vietnam, Thailand, China and Indonesia. Inequalities in federal and smaller unitary countries are considerably lower.

Figure 3.2: Regional disparities within non-industrial countries

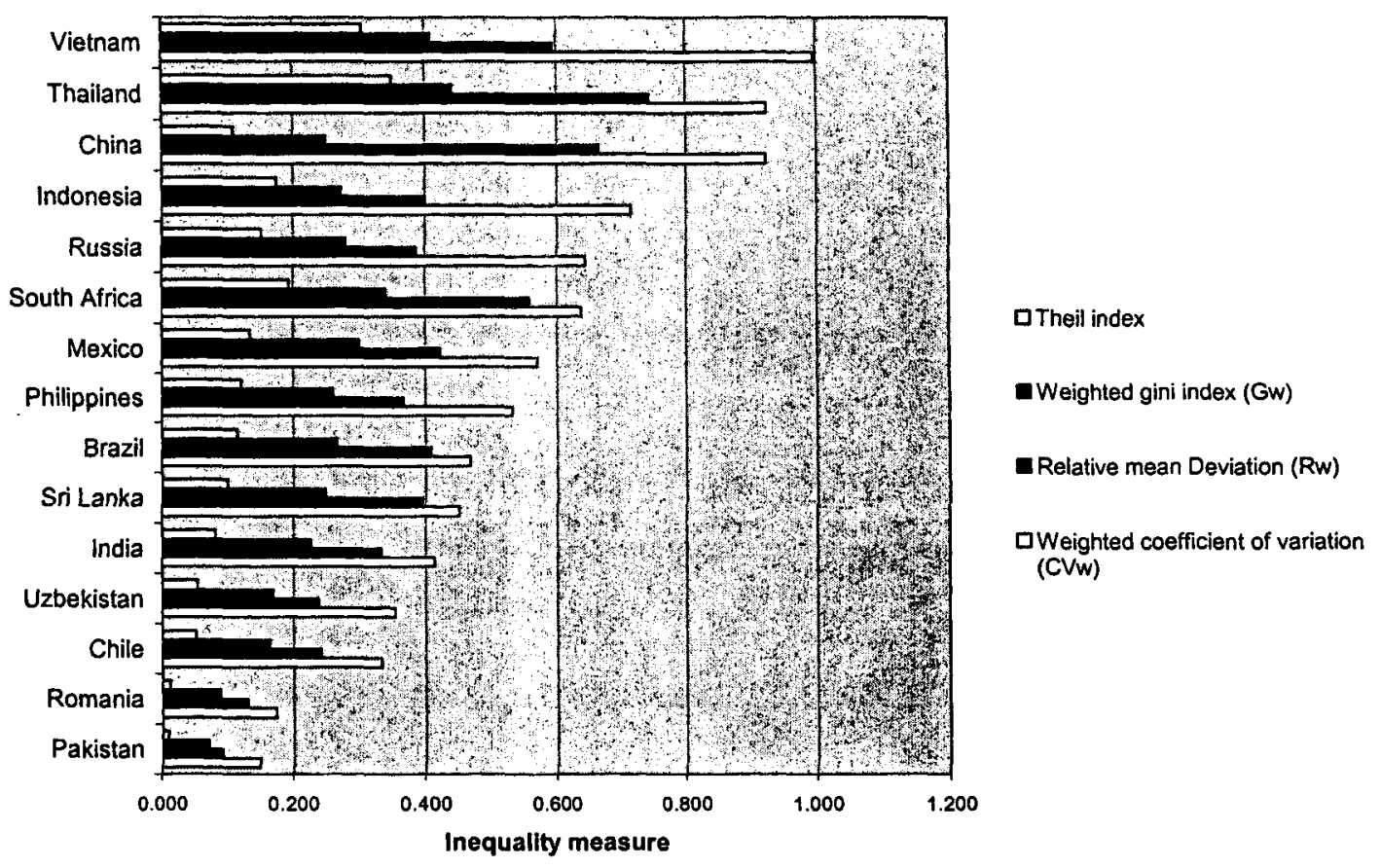

Pakistan, Romania, Chile, Brazil and Indonesia have lower values for the weighted measures than the unweighted ones, signifying that regions with extreme values of per capita GRDPs have smaller populations. On the other hand, the higher values for the weighted measures signify that India, Sri Lanka, Mexico, China and Thailand have regions with larger populations at the extremes of the per capita GRDP distribution. Uzbekistan, Philippines, Russia, South Africa and Vietnam have relatively more equal distribution of the populations in the 
regions at different points of the per capita GRDP distribution. The relative mean deviation, which we use to check for a few extreme deviations, is significantly different for Pakistan, Russia, Indonesia, Philippines, Uzbekistan and Vietnam.

\subsection{Federal vs. unitary countries}

We have seen above that, in general, federal countries are less unequal in terms of per capita GRDP than unitary countries. In this sub-section, we look at this relationship between decentralization and regional inequality. We regressed three weighted measures of inequality on a dummy variable representing whether a country is unitary or federal. ${ }^{5}$ The value of the dummy is and 1 if the country is unitary and 0 if the country is federal. For each measure of inequality we carried out two regressions - the first just on the unitary dummy and the second with the natural logarithm of population as the control variable. The measures of inequality used in the regression were from 1997 or the latest year available before 1997.

We obtained positive coefficients on the unitary dummy in all the regressions, signifying that unitary countries tend to be more unequal. However, except in the case of weighted $\mathrm{CV}$ as the dependent variable, the R-square value was too small or the coefficients were not statistically significant. Table $3.3 \mathrm{a}$ shows the results of the regression with weighted $\mathrm{CV}$ as the dependent variable and the natural logarithm of the country population as a control variable. The coefficient on the unitary dummy is positive and statistically significant at the $5 \%$ level with the two-tailed test. This provides some evidence for the proposition that centralization leads to greater regional disparities. The coefficient on the log of population also has a positive sign and is statistically significant at the $5 \%$ level with the two-tailed test. This is not surprising as, ceteris paribus, we would expect countries with larger populations to have greater regional inequalities. 


\section{Table 3.3a: Regression results}

\begin{tabular}{|l|l|}
\hline & \multicolumn{2}{|l|}{$\begin{array}{l}\text { Dependent variable: } \\
\text { Weighted CV }\end{array}$} \\
\hline Independent variable & Regression 2 \\
\hline Intercept & \multicolumn{2}{|l|}{-1.86} \\
\hline & $0.048^{\star \star}$ \\
\hline Unitary dummy & \multicolumn{2}{|l|}{0.28} \\
\hline & $0.016^{\star \star}$ \\
\hline $\log ($ Population) & \\
\hline & $0.022^{\star \star}$ \\
\hline \# of observations & \multicolumn{2}{|l}{0.344} \\
\hline R-square & \multicolumn{2}{|l}{} \\
\hline $\begin{array}{l}\text { P-values in italics } \\
\text { **significant at 5\% level (two-tailed test) }\end{array}$
\end{tabular}

We also computed the Spearman rank correlations of the weighted inequality measures with the unitary dummy. We computed the rank correlations in two different ways. First, we took just assigned an average rank of 5.5 to all the 9 federal countries and 15.5 to all the 12 unitary countries. In the second case, we ranked the countries within each group (federal or unitary) according to the level of decentralization. The level of decentralization was measured as the proportion of subnational government expenditures to that of total expenditures. Government expenditure data was taken from the IMF's Government Finance Statistics.

Table 3.3b: Spearman rank correlation

\begin{tabular}{|c|c|c|c|}
\hline & $\begin{array}{l}\text { Weighted } \\
\mathrm{CV}\end{array}$ & $\begin{array}{l}\text { Weighted Gini } \\
\text { index }\end{array}$ & Theil index \\
\hline Federal/Unitary & 0.458 & 0.423 & 0.458 \\
\hline $\begin{array}{l}\text { Federal/Unitary \& } \\
\text { Decentralization }\end{array}$ & 0.382 & 0.371 & 0.411 \\
\hline
\end{tabular}

Table $3.3 \mathrm{~b}$ presents the results of our calculations. The first row presents the rank correlations of the 22 countries in our sample with ranking according to only whether a country is federal or unitary. The second row shows the results when the ranking taking into account the level of decentralization in each country. In this case, our sample contains only 15 countries $^{6}$ as 
we did not have government expenditure data for the other six countries. All the correlation values are positive. These values may not be large, but they do question the conventional wisdom from the literature (Oates, 1972, Musgrave, 1959) that a centralized form of government is better for the reduction of inequalities between jurisdictions.

We conclude that significant regional inequalities persist in many developing countries. By most measures of regional inequality, developing countries are two to six times more unequal than developed countries. Similarly the unitary countries are more unequal than federal countries. This challenges the widespread assumption that centralized countries are better at equalizing economic differences among regions. On the contrary, the federal countries have a better record at ensuring regional equity.

\section{Regional income disparities and convergence}

In this section, the time trends of inequality for sixteen different countries are presented to discern the degree of convergence. Two of these countries are developed countries, Canada and the United States, and the rest are developing countries. Of the developing countries, five are federal countries and nine are unitary countries.

\subsection{Regional disparity trends in federal countries}

Figures $4.1 \mathrm{a}, 4.1 \mathrm{~b}$ and $4.1 \mathrm{c}$ show regional inequality trends in the federal countries over the time-period 1980 to 1999 . Figure 4.1 a plots the trends in the weighted CV, Figure $4.1 \mathrm{~b}$ the weighted Gini index, and Figure 4.1c the Theil index. Trends for different countries are plotted over different sub-periods depending on data availability. Table 4.1 presents evidence on $\beta$ convergence in the federal countries. This table contains the results of basic regressions of the growth rate of per capita GRDP on the logarithm of initial GRDP. The United States, Canada 
and Pakistan have the lowest levels of regional inequality followed by India, Brazil, Mexico and Russia respectively.

The United States has seen a decline in regional inequality from 1990 to 1994 after which it has stabilized. Canada's inequality has remained more or less constant from 1994 to 1998. Pakistan has seen a decline in inequality from 1990 to 1998, with a relatively sharp drop in 1994. Its level of inequality is comparable to that of Canada and the United States. The low levels of regional inequality in industrial countries is expected because of their being at an advanced stage of economic development ${ }^{7}$, and with their having few barriers to interregional trade and factor mobility. Pakistan's low level of regional inequality, uncharacteristic of developing countries, may be surprising, but it could be explained by the fact that Pakistan has a small number of provinces with the two richest provinces have over $80 \%$ of the country's population and that there is significant inter-provincial migration of labor and capital.

Figure 4.1a: Regional disparity trends in federal countries

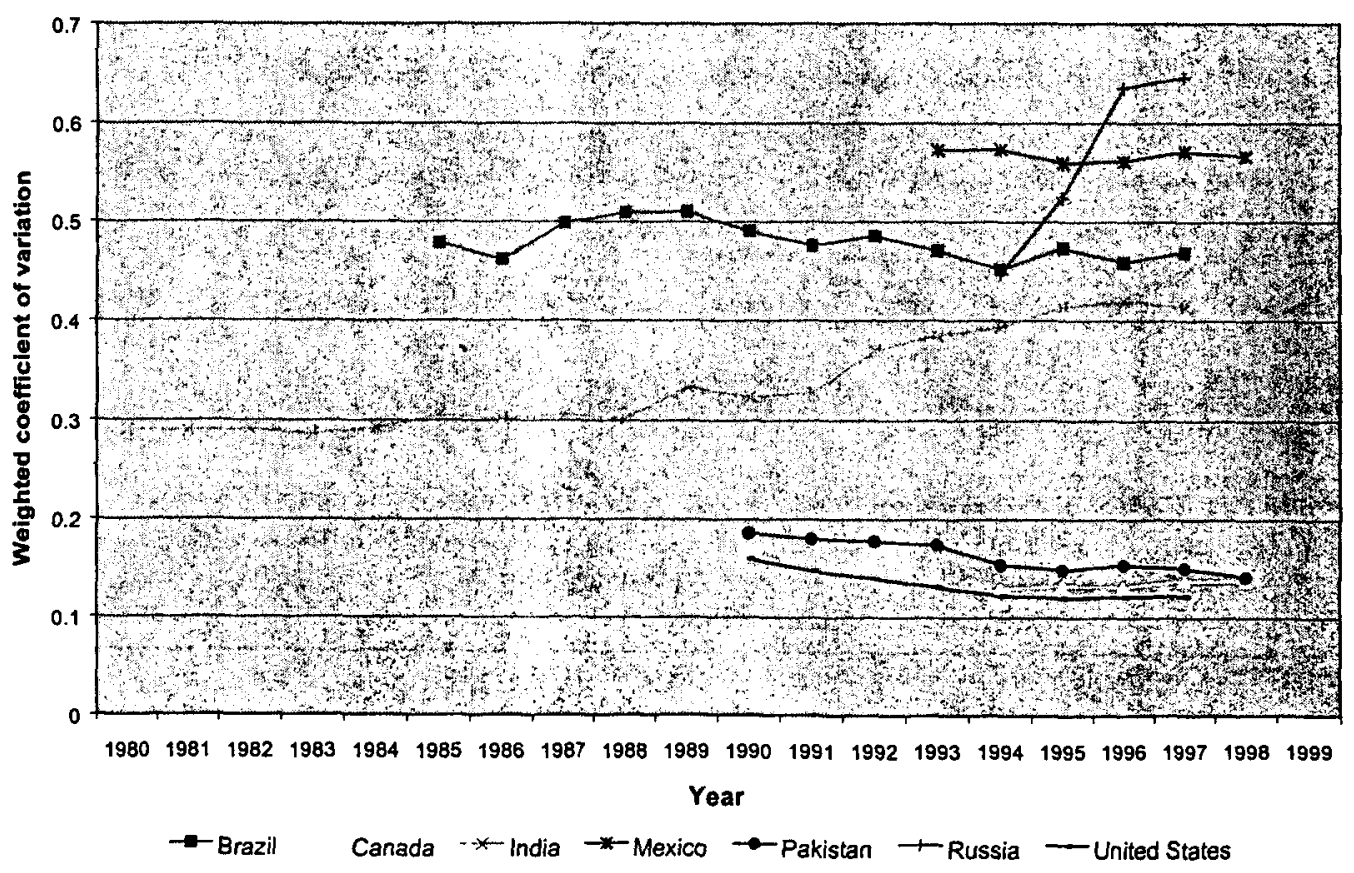


India has seen a constant rise in regional disparity from 1980 to 1996, followed by a slight fall in 1997. Regional inequality dramatically increased in 1992 after the liberalization reforms started. Its level of inequality has risen from about twice that of the United States in 1990 to more than three times in 1997. Our findings, which show that India has not witnessed $\sigma$ convergence, are consistent with other authors who have looked at regional inequalities in India. Bajpai and Sachs (1996) find evidence of divergence of state domestic products in the time period 1971-1993. Cashin and Sahay (1996) also find a widening in the dispersion of the net domestic products of Indian states from 1971-1991. Das and Barua (1996), Nagaraj, Varoudakis and Veganzones (2000), Rao, Shand and Kalirajan (1999), and Yagci (1999) also find similar evidence of divergence in India. Some of these authors have also found evidence against $\beta$ convergence in India. Rao, Shand and Kalirajan (1999) find that the growth of SDP per capita is positively related to initial levels for various sub-periods beginning in 1965 and ending in 199495. Yagci (1999) reports that higher income states have grown faster since 1980 compared to lower income states. Bajpai and Sachs (1996) also find evidence of a weak positive relationship between initial state domestic product and the economic growth rate in the time period 19711993. However, Cashin and Sahay (1996) report evidence of weak $\beta$ convergence. But they also point out that the speed of convergence, $1.5 \%$ per year, is slower than that of regional convergence in industrial economies (Australia, US, Canada and Japan), whose rate of convergence has been $2 \%$. In fact the speed of convergence is slower than between OECD countries, which is surprising result as one would expect faster convergence within national borders.

There could be several reasons for increasing regional inequality in India. One explanation could be that India is in a early stage of development and therefore is on the wrong side of the "inverted U" pattern of regional inequalities (Williamson, 1965). Another reason could be the 
relatively high barriers to inter-state trade in India. A third reason could be the perverse nature of the central government's regional development policies and the inter-governmental transfer system (Shah and Shankar, forthcoming).

Figure 4.1b: Regional disparity trends in federal countries

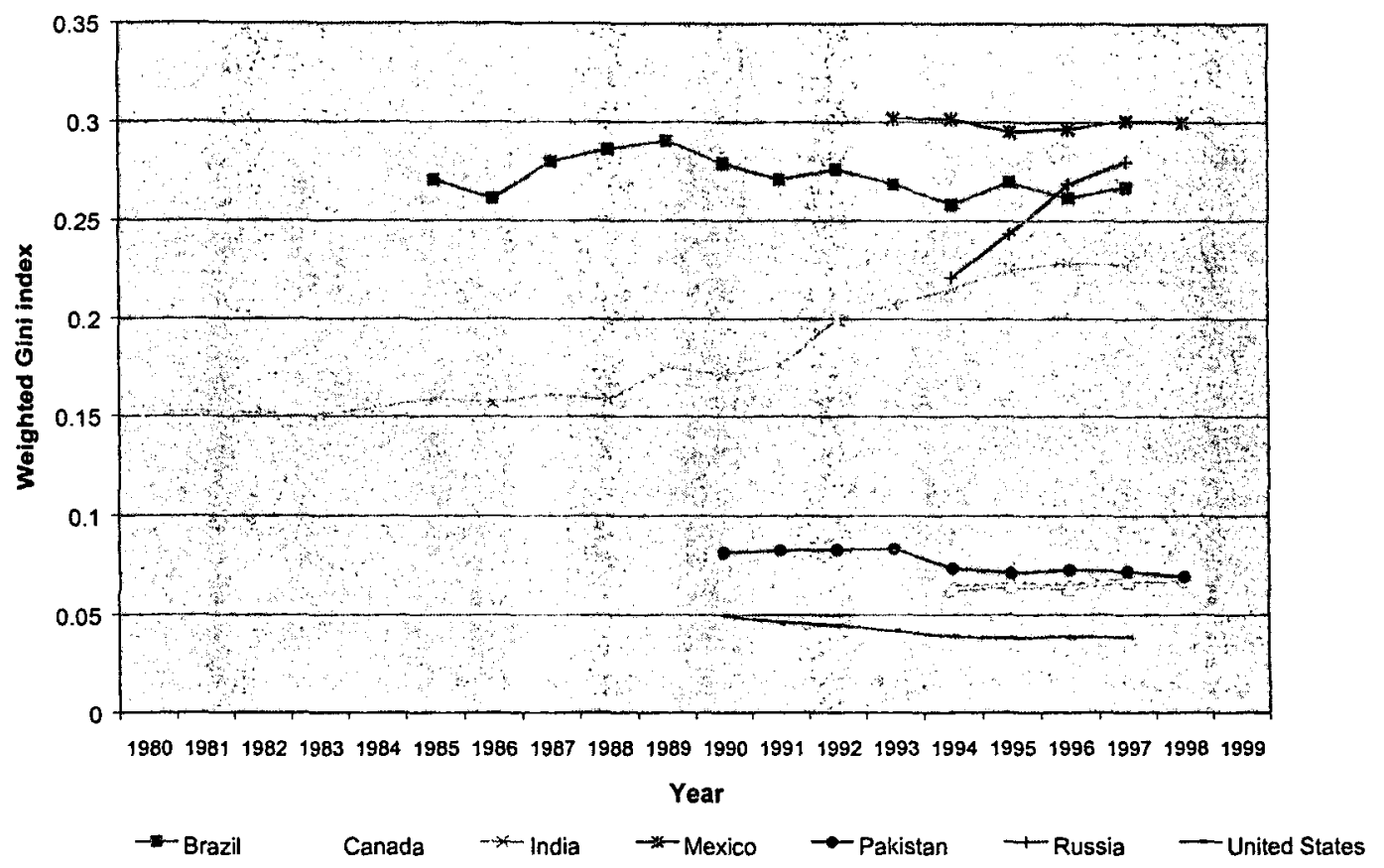

Brazil saw a rise in inequality in the 1980s, a slight fall in the early 1990s, and then a slight rise from 1995 to 1997. Its inequality has been around three to four times that of the US. More or less, the level of regional inequality has remained stable within a relatively narrow band. The weighted $\mathrm{CV}$ has fluctuated between a high of 0.51 and a low of 0.45 during this period. The weighted Gini index has varied between 0.29 and 0.26 , while the Theil index has stayed between 0.14 and 0.11 (see Appendix). 
Figure 4.1c: Regional disparity trends in federal countries

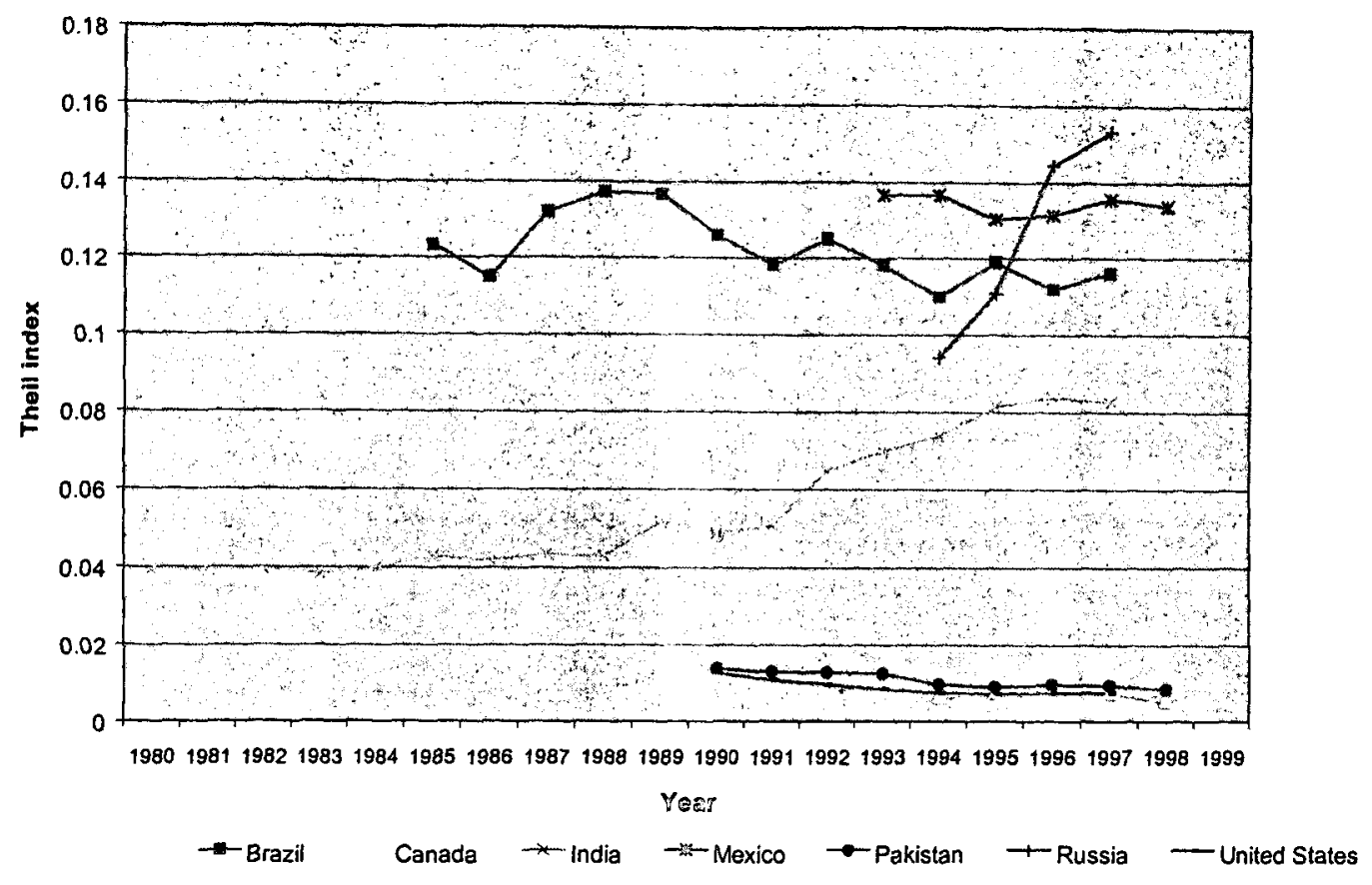

Mexico's regional inequality is around five times that of the US and has remained more or less stable in the 1990s. There is a slight dip in 1995, which was the year when the Mexican economy contracted $6.2 \%$, the worst recession since the Great Depression. Mexico is the most centralized of the federal countries in our sample. The state governments' are largely dependent on central transfers for their revenues. Transfers to states from revenue sharing were almost six times as large as states' own revenues in 1996 (Giugale et. al., 2000,19). This highly centralized nature of the Mexican federation may be one of the reasons for its high level of regional inequality (Shah and Shankar, forthcoming). 
Table 4.1: Beta convergence results in federal countries

\begin{tabular}{|l|l|l|l|l|l|l|}
\hline Country & $\begin{array}{l}\text { Time } \\
\text { period }\end{array}$ & $\begin{array}{l}\text { Independent } \\
\text { variable }\end{array}$ & Beta & p-value & R-square & $\begin{array}{l}\text { \# of } \\
\text { observations }\end{array}$ \\
\hline United States & & & & & & \\
\hline Canada & $1994-98$ & $\begin{array}{l}\log (1994 \\
\text { GDP }\end{array}$ & -0.005 & 0.75 & 0.012 & 11 \\
\hline Pakistan & & & & & & \\
\hline India & $1980-97$ & $\begin{array}{l}\log (1980) \\
\text { GDP }\end{array}$ & 0.017 & 0.04 & 0.306 & 14 \\
\hline Brazil & & & & & & \\
\hline Mexico & $1993-98$ & $\begin{array}{l}\log (1993 \\
\text { GDP }\end{array}$ & -0.002 & 0.735 & 0.004 & \\
\hline Russia & & & & & & \\
\hline
\end{tabular}

Russia has a dramatic rise in inequality from 1994 to 1997, with its 1997 weighted CV being $50 \%$ more than its 1994 value. During this period the Russian economy has undergone major structural transformation. It has undergone a long period of recession from 1990 till 1997 when it had a positive growth rate of $0.9 \%$. The increasing regional inequality may be due to the complex political and economic changes taking place in Russia, especially with economic power being concentrated in Moscow and a few other regions.

\subsection{Regional disparity trends in unitary countries}

Figures $4.2 \mathrm{a}, 4.2 \mathrm{~b}$ and $4.2 \mathrm{c}$ show regional inequality trends in the unitary countries over the time-period 1978 to 1999 . Figure 4.1a plots the trends in the weighted CV, Figure 4.1b the weighted Gini index, and Figure 4.1c the Theil index. Trends for different countries are plotted over different sub-periods depending on data availability. Table 4.2 presents evidence on $\beta$ convergence in the federal countries. This table contains the results of basic regressions of the growth rate of per capita GRDP on the logarithm of initial GRDP.

The smaller unitary countries in our sample have the lowest levels of regional inequality. Romania, Sri Lanka, Uzbekistan and Chile have relatively low levels of inequality, while Philippines, China, Indonesia and Thailand have high levels of inequality. In general, except for 
the smaller countries, the levels of inequality in these countries are significantly higher than in the federal countries.

Figure 4.2a: Regional disparity trends in unitary countries

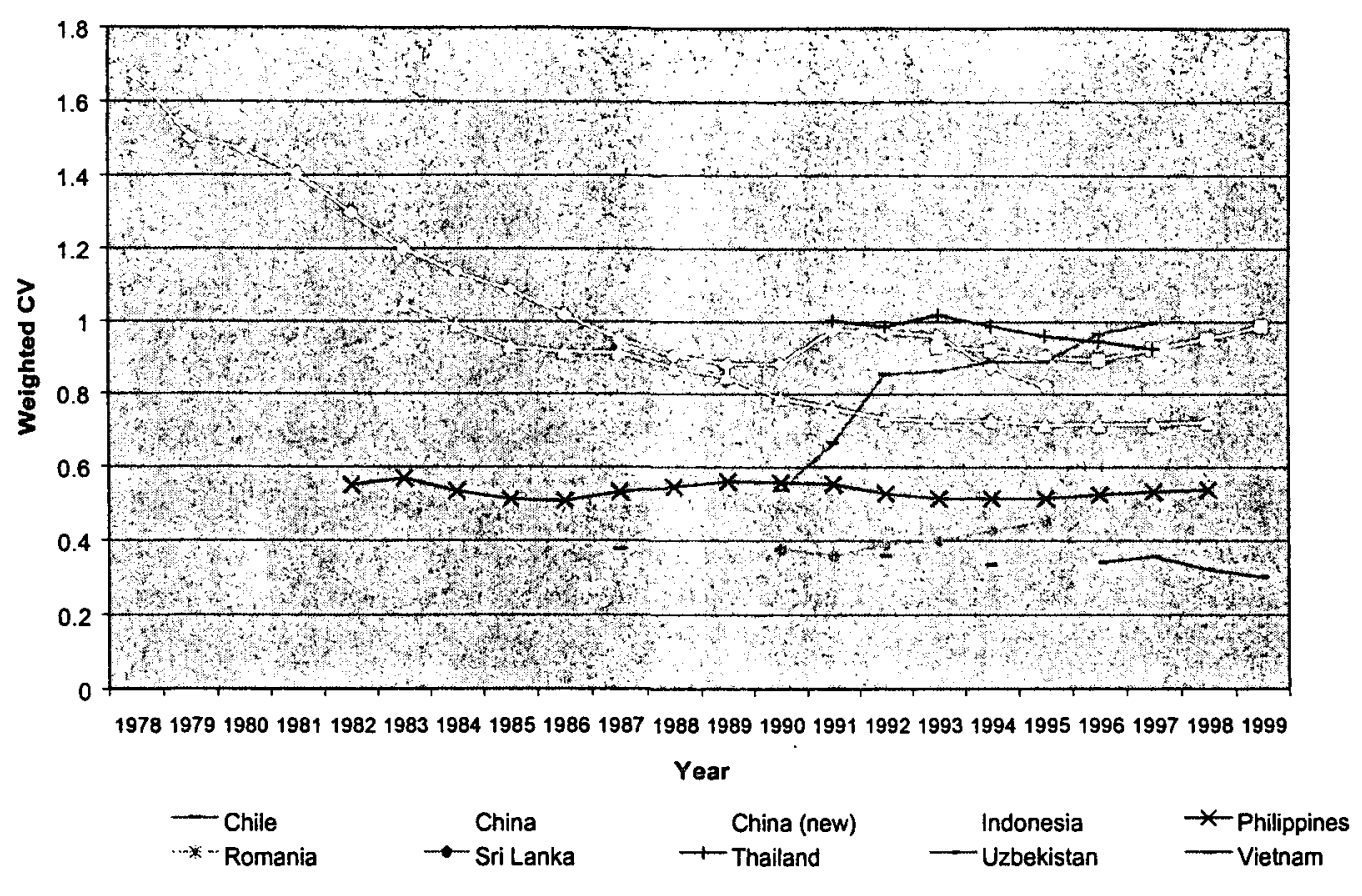

Romania, which has the lowest level of regional inequality experienced a rise in regional inequality during the period 1993 to 1996 . Its inequality, measured by the weighted CV, is around a third more than that of the US. Another transition country, Uzbekistan, has experienced a decline in its regional inequality during 1996 to 1999 . Its weighted CV is around two and a half times more than that of the US and Canada. Uzbekistan is a highly centralized country with 14 regions whose leaders can be sacked by the country's President. The most important activity happens in a sparsely populated region, Navoi, where most gold and uranium is mined. As gold is one of its major exports, this could account for some of Uzbekistan's regional inequality. 
Figure 4.2b: Regional disparity trends in unitary countries

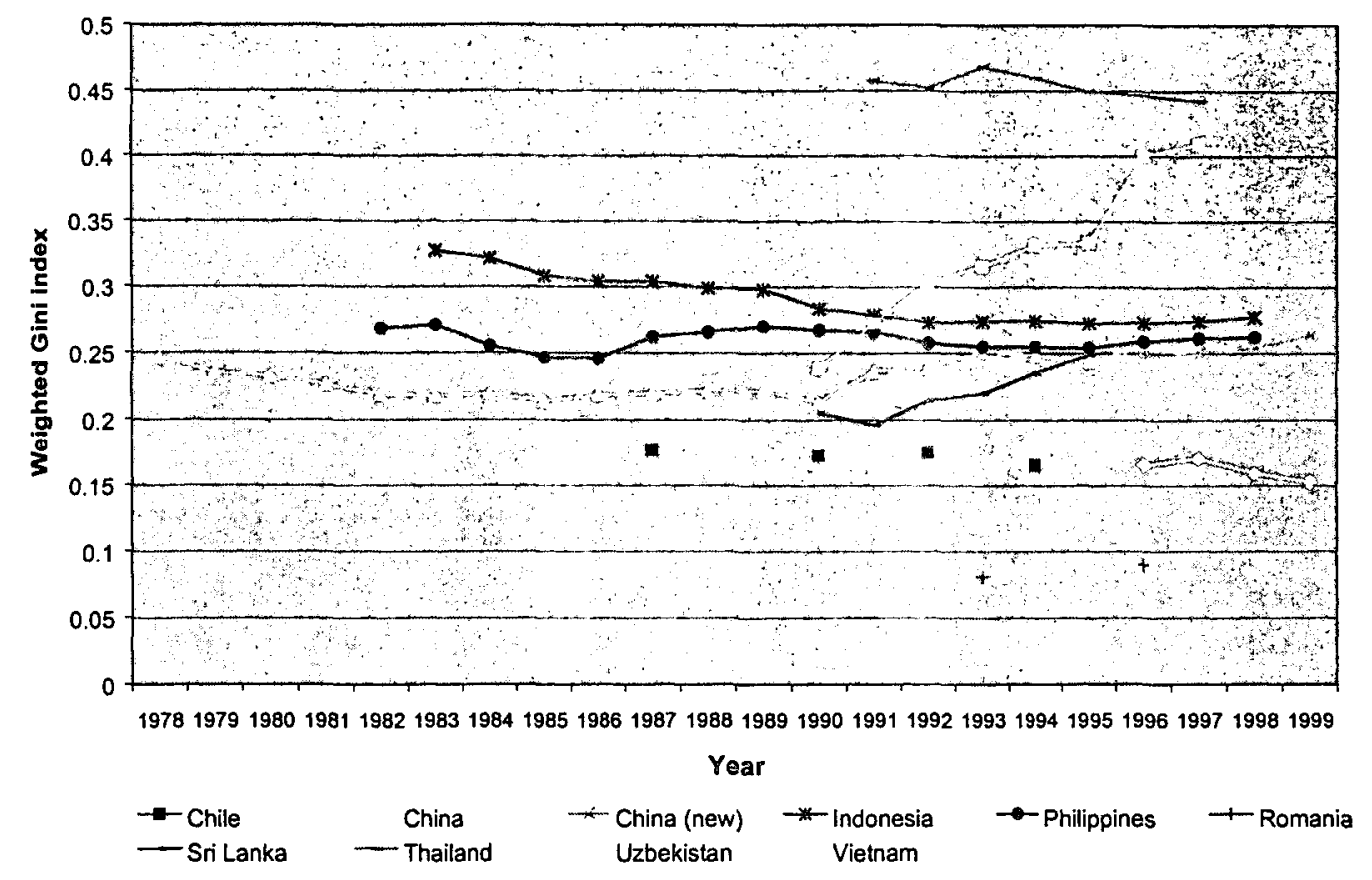

Chile has seen a decline in its level of regional inequality during the period 1987 to 1994. Its weighted CV has been around three times that of the US. The decline may be because Chile's development stage is on the right side of the "inverted U". Morevover market liberalization in Chile may be causing convergence. Economic activity is heavily concentrated in the central region. However, centralizing trends appear to have stopped, as a result of the mining boom in the north and the economic dynamism achieved in the extreme south by salmon breeding, tourism and large-scale methanol production. Tourism and export agriculture are strong engines of growth in the centre-north, while forestry, tourism, fruit production and traditional agriculture are important to the centre-south regions. Further, the traditionally strong centralist bias is being reversed through a gradual devolution of power to the municipalities, regional offices of ministries and public agencies, and other regional organizations (Source: EIU Country Profile). 
Although Sri Lanka has a lower level of inequality among the unitary countries, it is more unequal than India. Its weighted CV is almost four times that of the US. Sri Lanka saw a fall in regional inequality in 1991, after which it has steadily increased. Inadequate infrastructure development in rural areas, the concentration of industry close to the main ports and the airport, and the poor performance of the agricultural sector have led to an unequal distribution of the benefits of economic growth between regions. Because of its proximity to the port and airport, Western province is home to $85 \%$ of industry and generates over $40 \%$ of GDP, while predominantly agricultural areas such as North-western and Uva provinces remain backward due to the stagnation in coconut and domestic agriculture (Source: EIU Country Profile)

Figure 4.2c: Regional disparity trends in unitary countries

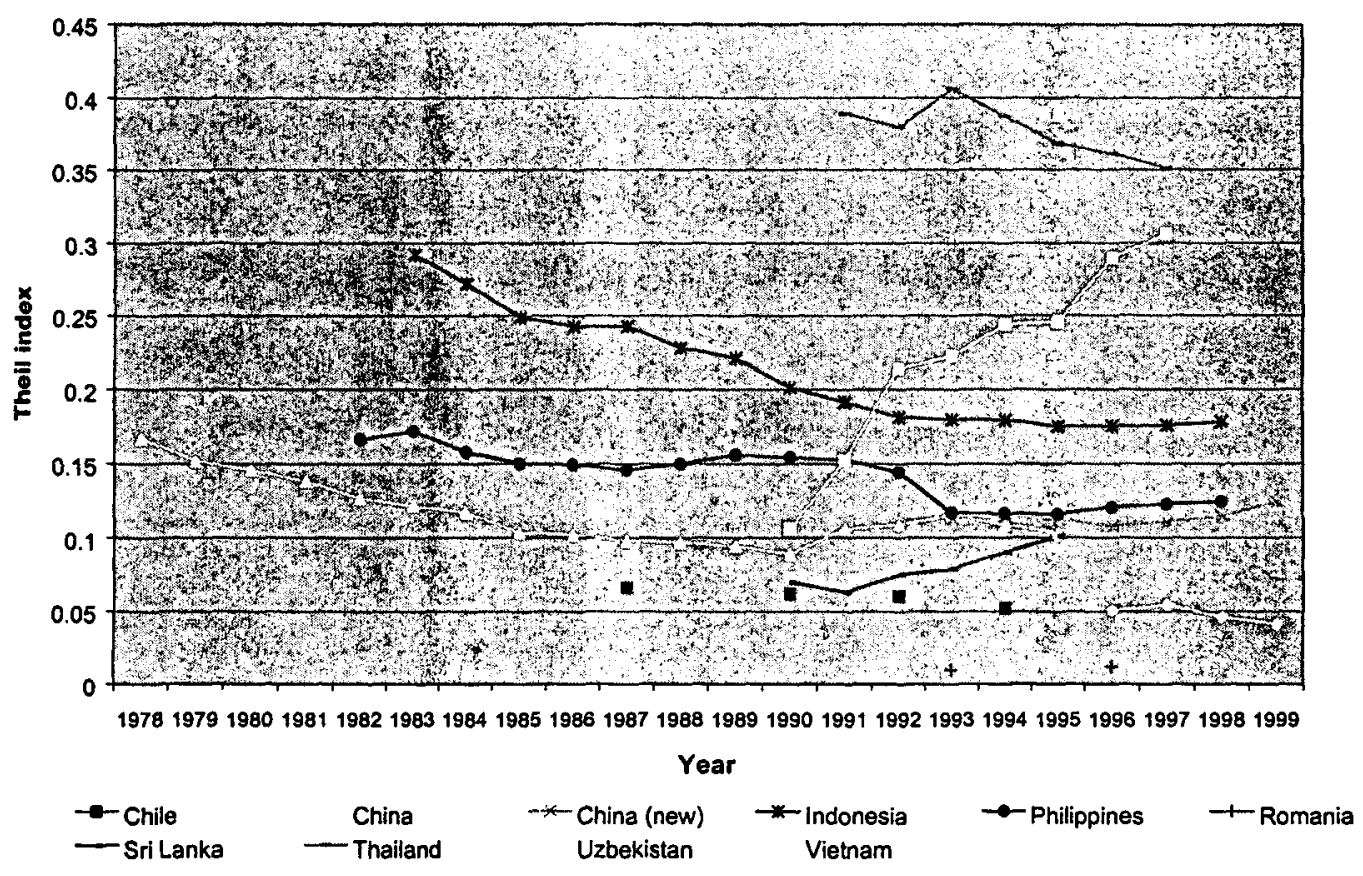

Vietnam has seen a dramatic rise in regional inequality in the 1990 s. The weighted CV has almost doubled during this period. There was a big spurt in inequality from 1990 to 1992 , after which it increase at a slower pace till 1995. 1995 to 1997 has seen another big increase. In 1990, 
Vietnam's weighted CV was more than three times as that of the US. In 1997, the weighted CV became more than eight times that of the US. Vietnam's economy has grown strongly during the 1990 s after it started on a policy of economic liberalization in the late 1980s. Its performance since 1989 was close to that of China. Since economic reform began in 1986, Ho Chi Minh City and the nearby provinces (especially Dong Nai and Binh Duong) have consolidated their position as the country's industrial heartland, although the Hanoi-Haiphong area has grown equaily quickly over the past few years. Left behind are the mountainous areas of the north and most of the north-central coastal provinces, which have traditionally been the poorest parts of the country. The widening regional inequality is counterbalanced to a limited extent by the budget, which raises revenue mainly in the wealthier areas but spreads the expenditure (on infrastructure, health and education) more widely.

Table 4.2: Beta convergence resultsin unitary countries

\begin{tabular}{|c|c|c|c|c|c|c|}
\hline Country & $\begin{array}{l}\text { Time } \\
\text { period }\end{array}$ & $\begin{array}{l}\text { Independent } \\
\text { variable }\end{array}$ & Beta & $p$-value & R-square & $\begin{array}{l}\# \text { of } \\
\text { observations }\end{array}$ \\
\hline \multicolumn{7}{|l|}{ Romania } \\
\hline Uzbekistan & $1996-99$ & $\sqrt{\log (1996 \text { GDP })}$ & -0.019 & 0.376 & 0.066 & $\overline{14}$ \\
\hline Chile & $1987-94$ & $\log (1987 \mathrm{GDP})$ & -0.0225 & 0.071 & 0.266 & $\overline{13}$ \\
\hline Sri Lanka & $1990-95$ & $\log (1990 \mathrm{GDP})$ & 0.018 & 0.637 & 0.047 & 7 \\
\hline \multicolumn{7}{|l|}{ Vietnam } \\
\hline \multirow[t]{5}{*}{ Philippines } & $1982-98$ & $\log (1982$ GDP $)$ & -0.007 & 0.315 & 0.092 & 13 \\
\hline & $1982-86$ & $\log (1982$ GDP $)$ & -0.025 & 0.023 & 0.389 & $\overline{13}$ \\
\hline & $1986-90$ & $\log (1986$ GDP $)$ & 0.018 & 0.441 & 0.05 & $\overline{14}$ \\
\hline & $1990-94$ & $\log (1990$ GDP $)$ & -0.012 & 0.443 & 0.05 & $\overline{14}$ \\
\hline & 1994-98 & $\log (1994$ GDP $)$ & 0.001 & 0.954 & 0 & 15 \\
\hline \multirow[t]{2}{*}{ Indonesia } & $1983-92$ & $\log (1983$ GDP $)$ & -0.019 & 0 & 0.5 & 27 \\
\hline & 1993-1998 & $\log (1993 \mathrm{GDP})$ & -0.006 & 0.376 & 0.031 & 27 \\
\hline \multicolumn{7}{|l|}{ China } \\
\hline Thailand & & & & & & \\
\hline
\end{tabular}

There is no major discernible trend in regional inequality in the Philippines according to the weighted measures during the period 1982 to 1998 . Inequality increased in 1983, then declined till about 1986, after which it increased till 1989. After 1989 there was a decline till about 1995, and then there has been an increase from 1995 to 1998 . The weighted $\mathrm{CV}$ of 
Philippines has varied from about three and a half times that of the US in 1990 to about four and a half times in 1997. Appendix A11 shows that the weighted measures, which were higher than the unweighted ones in the 1980s have fallen below the unweighted measures in the 1990s. This might mean that most of the bigger population regins have tended to converge nearer the mean per capita GRDP, while the smaller population regions have moved to the extremes. Futher, the relative mean deviation is significantly different from the weighted $\mathrm{CV}$, which would mean that there are a few extreme outliers.

The figures for overall GDP of P2.42trn (US \$85.7bn) and for GDP per head of P32,961 (US $\$ 1,166$ ) in 1997 conceal a wide disparity in wealth between different regions of the country. The National Capital Region (NCR), the region centered on Manila, accounts for $14 \%$ of the population and produces one- third of GDP. Its per capita GRDP is well over double the national average. Only two other regions - South Tagalog and Cordillera Administrative Region-have income per head that is above the national average, while four register around half that figure and the four autonomous provinces in Mindanao only one-third. This reflects the concentration of manufacturing activities in the Manila area. However, growth points have been developing in other regions, where industrial parks have been the focus for much investment, both domestic and foreign, in recent years. ${ }^{8}$

Indonesia has seen a constant drop in regional inequality since 1983 . The drop was more pronounced till about 1992, after which the decline slowed. With the 1997 economic crisis, regional inequality increased slightly in 1997 and 1998. In 1983, Indonesia was almost four times as unequal as India, in 1985, its weighted CV was almost twice as unequal as Brazil, and in 1990, it was five times as unequal as the US. In 1997, Indonesia's weighted CV was three-fouths more than that of India, around $55 \%$ more than that of Brazil and six times that of the US. In 
other words, Indonesia has improved its position relative to India and Brazil, but in the 1990s its rate of convergence has been slower than that of the US.

Akita and Lukman (1995) also find a constant decine in the weighted CV from 1975 to 1992. When they exclude the mining sector, however, no trend is discernible in regional inequality. They conclude that the decreasing weighted $\mathrm{CV}$ could be attributed to the decline of the mining sectors's share in GDP. Akita and Lukman also find that the contribution of the tertiary sector to regional inequality has declined during this period while that of the secondary sector has increased. Indonesia has averaged an annual growth rate of 6\% from 1970-1996.

Asra (1989) estimates the Gini index for regional inequality for expenditure for the period 1969 to 1981 . He finds that if one adjusts the standard inequality measures for the differential impact of inflation on different expenditure groups, regional inequality in Indonesia has increased from 1969 to 1976 and then declined from 1976 to 1981.

Garcia and Soelistianingsih (1998) find evidence for both $\sigma$ convergence and $\beta$ convergence for per capita GRDP during the period 1975-1993. But they also find that regions at the top and bottom of the distribution in 1983 remained at the top and bottom of the distribution in 1993. Our dataset also shows the same result during the period 1983 to 1998 - the top and bottom regions remained the same.

Regional inequality in China fell from 1978 to 1990 after which there was an increase till 1993. Inequality fell again from 1993 to 1996 and then increased till 1999. The weighted CV for China has varied from around five times that of the US in 1990 to around eight times in 1999. Its weighted $\mathrm{CV}$ has been higher than almost all other countries in our sample. Only Thailand in the early to mid 1990s and Vietnam in the late 1990s has had a higher value for the weighted CV. 
However, on other weighted measures of inequality - the weighted Gini index and the Theil index - China has performed better than Indonesia, Thailand, Vietnam and the Philippines. This is intriguing especially as the weighted CV for China is higher than the unweighted CV, while the weighted Gini index is lower than the unweighted Gini index (see Appendices A9.1 and A9.2). This could be due to the presence of provinces with larger populations at the lower end of the distribution. In fact almost $70 \%$ of the population is in provinces with per capita GRDP below the national average. The median per capita GRDP is significantly lower than the mean per capita GRDP. For example, the national mean GRDPs per capita in current prices for 1978 and 1999 are Rmb 357 (US \$210) and Rmb 7242 (US \$826) respectively. The corresponding population weighted medians are Rmb 313 (US \$184) and Rmb 5400 (US \$621) respectively. This would skew the estimates of weighted $\mathrm{CV}$, which is also evident from the fact that the relative mean deviation is significantly lower than the weighted CV.

Several authors have looked at regional inequality in China. Jian, et. al. (1996) have found that the economies of Chinese provinces converged somewhat during 1952-1965, then diverged during the cultural revolution years of 1966-1977. After 1977 till about 1990, during the reform period, they find statistically significant evidence for $\beta$ convergence. Raiser (1998) also finds evidence of $\beta$ convergence after 1978 till about 1990. Both studies find that the economies of the Chinese provinces diverge after 1990. A look at $\sigma$ convergence yields a similar picture. Jian, et. al., find that the standard deviation of log of real per capita GRDP fell slightly during 1952-1965, increased from 1966-1977 and fell significantly during 1977-1990. The period after 1990 has seen an increase in the dispersion of per capita GRDP. Raiser finds similar results in the period 1978-1992 using the coefficient of variation. 
Jian, et. al. (1996) suggest that there were two forces at work during 1952-1965, a government induced bias against agricultural regions causing divergence, and unidentified forces pushing towards convergence leading to slight overall convergence. During $1966-1977$, the autarkic years of the cultural revolution led to divergence, while the market reforms after 1978 led to convergence. However, Jian et. al., point out that almost all of the convergence is due to a narrowing of income inequality among the coastal provinces, rather than a narrowing of inequality between the coastal and interior provinces or a narrowing of inequality in the interior provinces. Raiser (1998) finds similar results. The divergence between the coast and the interior is in a large part due to the special economic privileges (in tax policy and trade policy) granted to the coastal regions as part of the economic reforms. The contradiction between the poor, inaccessible and inhospitable terrain of most of the interior and the more fertile coastal deltas and plains has been exacerbated by these reforms. The coastal areas have been far more able to achieve rapid growth, while the interior provinces have been left behind.

In our sample, Thailand has the highest level of regional inequality. Its level of inequality has slightly declined during the time period 1991 to 1997 . The weighted CV has varied from seven times that of the US in 1991 to about a little more than seven and a half times in 1997. The weighted measures have been greater than the unweighted measures throughout this period (see Appendix A13), signifying that large population regions are at the extreme ends of the distribution. Although rapid growth rates have led to a steady rise in real income levels per head over the last 30 years, there are alarming disparities in national wealth distribution. Income per head in the north-east is only $52 \%$ of the national average and just over $20 \%$ of that in the Bangkok Metropolitan Area. Recent governments have responded by pushing economic decentralization, generally with disappointing results. This could be due to the strong role of the center in regional development. Since 1993 about $65 \%$ of promoted investment has gone outside 
Bangkok, but most only reached the Eastern Seaboard Industrial Zone, an hour or so from the city. The Board of Investment (BOI) responded in 1997 by setting up the country's first special economic zones (SEZs) in 13 of the poorest provinces, but there had been little response by early 1999 because of a perception of poor infrastructure in these areas. Tax incentives will be targeted at 21 industries located in the zones. Specialist free-trade zones are also being established for more technologically advanced industries. The Eighth Five-Year Development Plan incorporates plans for decentralization, and the old zones system seems likely to be replaced by more localized incentives. ${ }^{9}$

\section{Regional inequalities and convergence - a scorecard on national policies for regional development}

The empirical analysis presented in the earlier sections is summarized in Table 5.1. The following conclusions emerge from this analysis.

Regional development policies have failed in almost all countries- federal and unitary alike. Of the ten countries listed in Table 5.1 with high or substantial degree of regional income inequalities, only one country (Thailand) has experienced convergence in regional incomes. Federal countries, however, do better in restraining regional inequalities. This is because widening regional disparities pose a greater political risk in federal countries. In such countries inequalities beyond a threshold may lead to calls for separation by both the richest and the poorest regions. While the poorest regions may consider such inequalities as manifestation of regional injustice, the richest regions may view a union with the poorest regions possibly holding them back in their drive to prosperity in the long run. 
Table 5.1 : Regional Inequalities and Convergence: A Summary View

\begin{tabular}{|c|c|c|c|c|}
\hline Country & $\begin{array}{l}\text { Federal }[\mathbf{F}] \\
\text { [Unitary }[\mathbf{U}]\end{array}$ & $\begin{array}{l}\text { Degree of Regional } \\
\text { Inequality }\end{array}$ & $\begin{array}{l}\text { Trends: Sigma Convergence } \\
\text { [C]/Divergence [D]/Stable [S] }\end{array}$ & $\begin{array}{l}\text { Trends: Beta Convergence }[\mathrm{C}] \\
\text { /Divergence }[\mathrm{D}] / \text { Stable }[\mathrm{S}]\end{array}$ \\
\hline Vietnam & $\mathrm{U}$ & High & D (90-97) & \\
\hline Thailand & $\mathrm{U}$ & High & C (91-97) & \\
\hline China & $\mathrm{U}$ & High & $\begin{array}{l}C(78-90) \\
D(90-93) \\
C(93-96) \\
\text { D (96-99) }\end{array}$ & \\
\hline Indonesia & U & High & $\begin{array}{l}C(83-95) \\
\text { D (95-98) }\end{array}$ & $\begin{array}{l}\text { C (83-92) } \\
\text { S- }(93-98)\end{array}$ \\
\hline Russia & $\mathrm{F}$ & High & D (94-97) & \\
\hline Mexico & $\mathbf{F}$ & Substantial & $S(93-98)$ & S- (93-98) \\
\hline Philippines & $\mathbf{U}$ & Substantial & $\begin{array}{l}C(82-86) \\
D(86-89) \\
C(89-95) \\
D(95-98)\end{array}$ & $\begin{array}{l}C(82-86) \\
S+(86-90) \\
S-(90-94) \\
S+(94-98) \\
\end{array}$ \\
\hline Brazil & F & Substantial & $\begin{array}{l}D(85-89) \\
C(89-94) \\
D(94-97)\end{array}$ & \\
\hline Sri Lanka & $\mathrm{U}$ & Substantial & $\mathrm{D}(90-95)$ & $S+(90-95)$ \\
\hline India & $\mathrm{F}$ & Substantial & $\mathrm{D}(80-97)$ & $D(80-97)$ \\
\hline
\end{tabular}




\begin{tabular}{|l|l|l|l|l|}
\hline Uzbekistan & U & Moderate & C (96-99) & S- (96-99) \\
\hline Chile & U & Moderate & C (87-94) & C (87-94) \\
\hline France & U & Moderate & & \\
\hline Italy & U & Moderate & & \\
\hline Spain & L & Low & & \\
\hline $\begin{array}{l}\text { Former West } \\
\text { Germany }\end{array}$ & F & Low & & \\
\hline $\begin{array}{l}\text { United } \\
\text { Kingdom }\end{array}$ & U & Low & D (93-96) & \\
\hline Romania & U & Low & C (90-98) & \\
\hline Pakistan & F & Low & S (94-98) & S- (94-98) \\
\hline $\begin{array}{l}\text { Canada } \\
\text { United States }\end{array}$ & F & Low & C (90-97) & \\
\hline
\end{tabular}

Note: In the beta convergence column a $+(-)$ sign after $\mathrm{S}$ denotes a positive (negative) coefficient on the log of initial GDP, but this coefficient is not statistically significant at the $10 \%$ level. 
The table further provides the following classification of countries by the degree of convergence.

Countries experiencing regional income divergence: Vietnam, China, Indonesia, Russia, Philippines, Brazil, Sri Lanka, India and Romania.

Countries experiencing no significant change in regional income variations: Mexico anc Canada.

Countries experiencing regional income convergence: Thailand, Uzbekistan, Chile, Pakistan and USA

Regional development outcomes observed here provide a revealing look at the impact of regional development policies ${ }^{10}$. For example countries experiencing divergence by and large focus on interventionist policies for regional development. On the other hand countries experiencing convergence have had a hands off approach to regional development policies and instead focused on policies to promote a common economic union through removal of barriers to factor mobility and ensuring minimum standards of basic services across the nation. For example, regional income convergence in Chile is largely attributable to economic liberalization and removing distortions in the economy so that regions could discover their own comparative advantage in the economic union. In Pakistan and USA such convergence is attributable to greater factor mobility rather than region specific policies. This leads us to conclude that paradoxically creation of a level playing field is more helpful to disadvantaged regions rather than following paternalistic protectionist policies. 


\section{Appendix: Regional disparity trends}

\section{A1 Canada}

Table A1: Regional disparity trends in Canada

\begin{tabular}{|c|c|l|l|l|l|l|c|}
\hline & Yax/Min & $\begin{array}{l}\text { Simple } \\
\text { Coefficient } \\
\text { of variation } \\
(\mathrm{CVu})\end{array}$ & $\begin{array}{l}\text { Weighted } \\
\text { coefficient } \\
\text { of variation } \\
(\mathrm{CVW})\end{array}$ & $\begin{array}{l}\text { Relative } \\
\text { mean } \\
\text { Deviation } \\
(\mathrm{RW})\end{array}$ & $\begin{array}{l}\text { Unweighted } \\
\text { gini index } \\
(\mathrm{Gu})\end{array}$ & $\begin{array}{l}\text { Weighted } \\
\text { gini index } \\
(\mathrm{Gw})\end{array}$ & $\begin{array}{l}\text { Theil } \\
\text { index (T) }\end{array}$ \\
\hline 1994 & 1.781 & 0.193 & 0.129 & 0.112 & 0.114 & 0.063 & 0.006 \\
\hline 1995 & 1.785 & 0.205 & 0.132 & 0.118 & 0.119 & 0.065 & 0.008 \\
\hline 1996 & 1.949 & 0.221 & 0.131 & 0.116 & 0.128 & 0.064 & 0.011 \\
\hline 1997 & 1.838 & 0.201 & 0.137 & 0.123 & 0.118 & 0.067 & 0.008 \\
\hline 1998 & 1.718 & 0.195 & 0.137 & 0.127 & 0.113 & 0.068 & 0.006 \\
\hline
\end{tabular}

Figure A1: Regional disparity trends in Canada

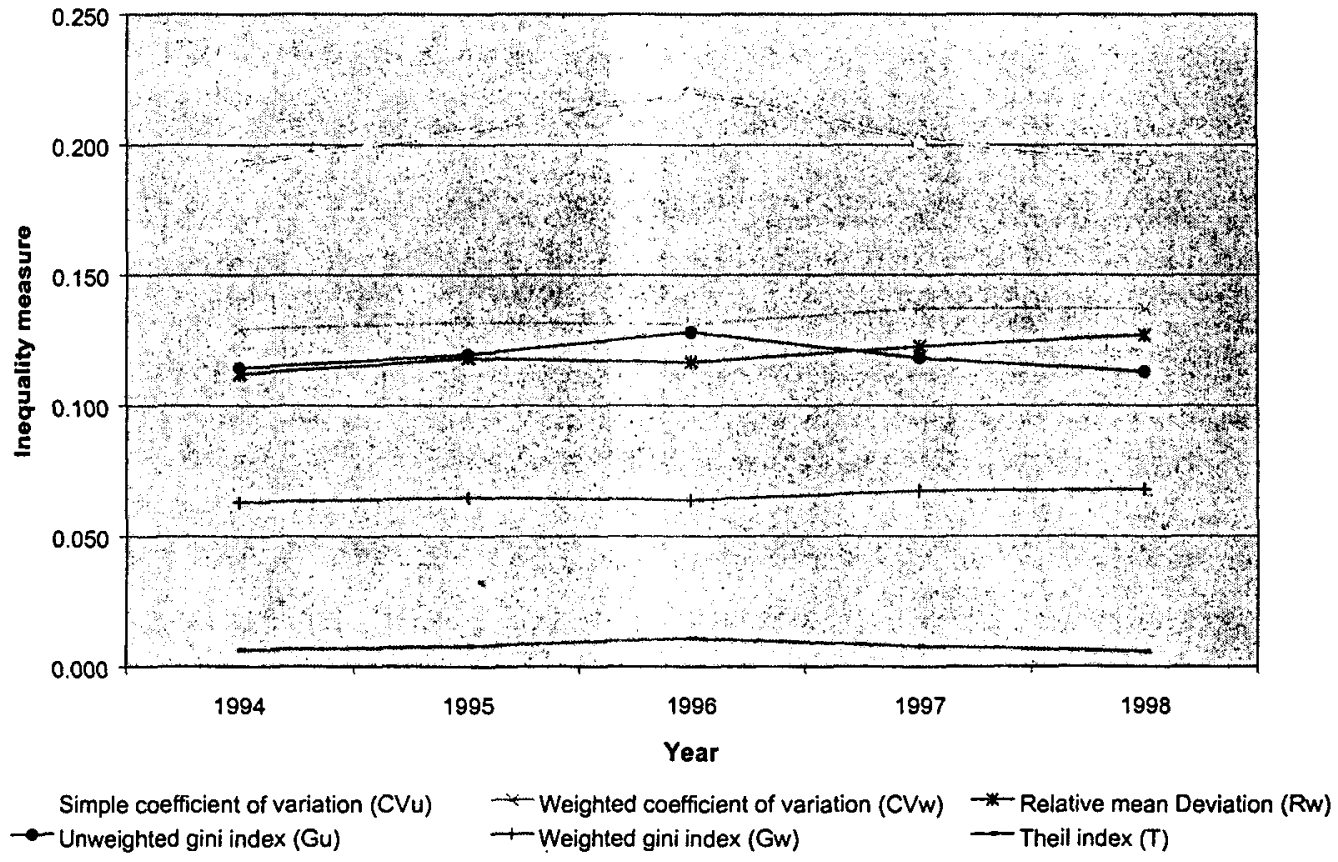




\section{A2 United States}

Table A2: Regional disparity trends in the United States

\begin{tabular}{|c|c|l|l|l|l|l|l|}
\hline & & $\begin{array}{l}\text { Simple } \\
\text { coefficient } \\
\text { of variation } \\
(\mathrm{CVU})\end{array}$ & $\begin{array}{l}\text { Weighted } \\
\text { coefficient } \\
\text { of variation } \\
(\mathrm{CVW})\end{array}$ & $\begin{array}{l}\text { Relative } \\
\text { mean } \\
\text { Deviation } \\
(\mathrm{RW})\end{array}$ & $\begin{array}{l}\text { Unweighted } \\
\text { gini index } \\
(\mathrm{Gu})\end{array}$ & $\begin{array}{l}\text { Weighted } \\
\text { gini index } \\
(\mathrm{GW})\end{array}$ & $\begin{array}{l}\text { Theil } \\
\text { index (T) }\end{array}$ \\
\hline 1990 & 2.871 & 0.229 & 0.159 & 0.132 & 0.118 & 0.049 & 0.013 \\
\hline 1991 & 2.522 & 0.207 & 0.147 & 0.122 & 0.109 & 0.046 & 0.011 \\
\hline 1992 & 2.281 & 0.189 & 0.139 & 0.114 & 0.102 & 0.044 & 0.010 \\
\hline 1993 & 2.157 & 0.180 & 0.130 & 0.105 & 0.097 & 0.042 & 0.008 \\
\hline 1994 & 1.966 & 0.167 & 0.122 & 0.096 & 0.092 & 0.039 & 0.007 \\
\hline 1995 & 1.976 & 0.166 & 0.120 & 0.095 & 0.091 & 0.038 & 0.007 \\
\hline 1996 & 1.943 & 0.163 & 0.121 & 0.096 & 0.090 & 0.039 & 0.007 \\
\hline 1997 & 1.927 & 0.162 & 0.122 & 0.097 & 0.090 & 0.039 & 0.007 \\
\hline
\end{tabular}

Figure A2: Regional disparity trends ofic the US

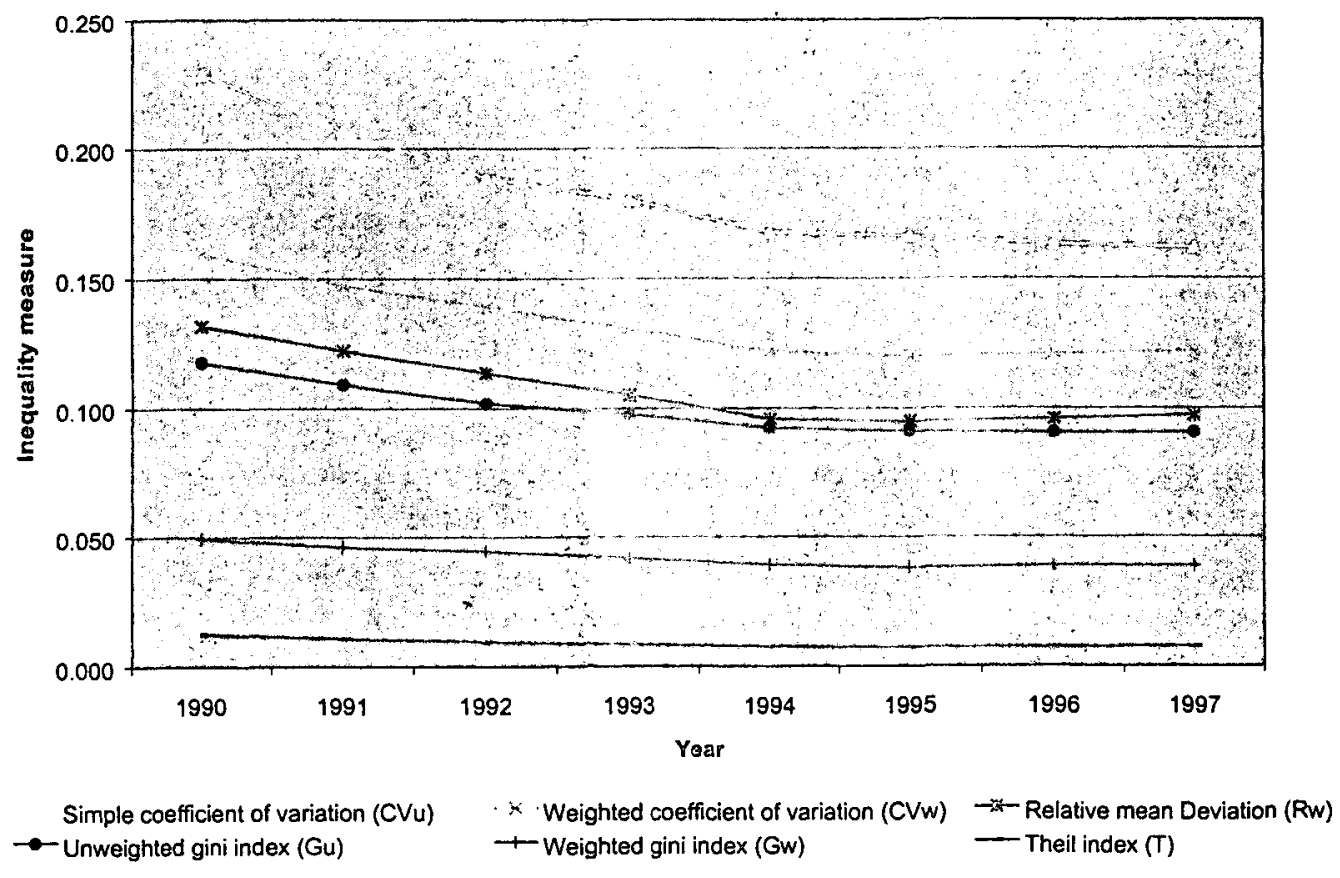




\section{A3 Brazil}

Table A3: Regional disparity trends in Brazil

\begin{tabular}{|c|c|c|c|c|c|c|c|}
\hline & $\begin{array}{l}\text { Max/Min } \\
(\mathrm{MMR})\end{array}$ & $\begin{array}{l}\text { Simple } \\
\text { coefficient } \\
\text { of variation } \\
(\mathrm{CVu})\end{array}$ & $\begin{array}{l}\text { Weighied } \\
\text { coefficien } \\
\text { of variation } \\
(\mathrm{CVW})\end{array}$ & $\begin{array}{l}\text { Relative } \\
\text { mean } \\
\text { Deviation } \\
(\mathrm{RW})\end{array}$ & $\begin{array}{l}\text { Unweighted } \\
\text { gini index } \\
(\mathrm{Gu})\end{array}$ & $\begin{array}{l}\text { Weighted } \\
\text { gini index } \\
(\mathrm{GW})\end{array}$ & $\begin{array}{l}\text { Theil } \\
\text { index (T) }\end{array}$ \\
\hline 1985 & 7.679 & 0.491 & 0.478 & 0.411 & 0.281 & 0.270 & 0.123 \\
\hline 1986 & 6.995 & 0.479 & 0.462 & 0.399 & 0.275 & 0.261 & 0.115 \\
\hline 1987 & 8.287 & 0.510 & 0.498 & 0.423 & 0.287 & 0.280 & 0.132 \\
\hline 1988 & 8.457 & 0.525 & 0.509 & 0.434 & 0.296 & 0.286 & 0.137 \\
\hline 1989 & 8.314 & 0.550 & 0.510 & 0.441 & 0.340 & 0.290 & 0.137 \\
\hline 1990 & 7.254 & 0.525 & 0.490 & 0.432 & 0.322 & 0.279 & 0.126 \\
\hline 1991 & 8.775 & 0.571 & 0.475 & 0.416 & 0.334 & 0.271 & 0.118 \\
\hline 1992 & 7.771 & 0.567 & 0.485 & 0.432 & 0.340 & 0.276 & 0.125 \\
\hline 1993 & 7.409 & 0.551 & 0.470 & 0.421 & 0.335 & 0.268 & 0.118 \\
\hline 1994 & 6.968 & 0.532 & 0.452 & 0.399 & 0.326 & 0.258 & 0.110 \\
\hline 1995 & 7.576 & 0.551 & 0.473 & 0.419 & 0.333 & 0.269 & 0.119 \\
\hline 1996 & 6.881 & 0.550 & 0.458 & 0.405 & 0.330 & 0.261 & 0.112 \\
\hline 1997 & 7.567 & 0.563 & 0.468 & 0.409 & 0.334 & 0.267 & 0.116 \\
\hline
\end{tabular}

Figure A3: Regional disparity trends in Brazil

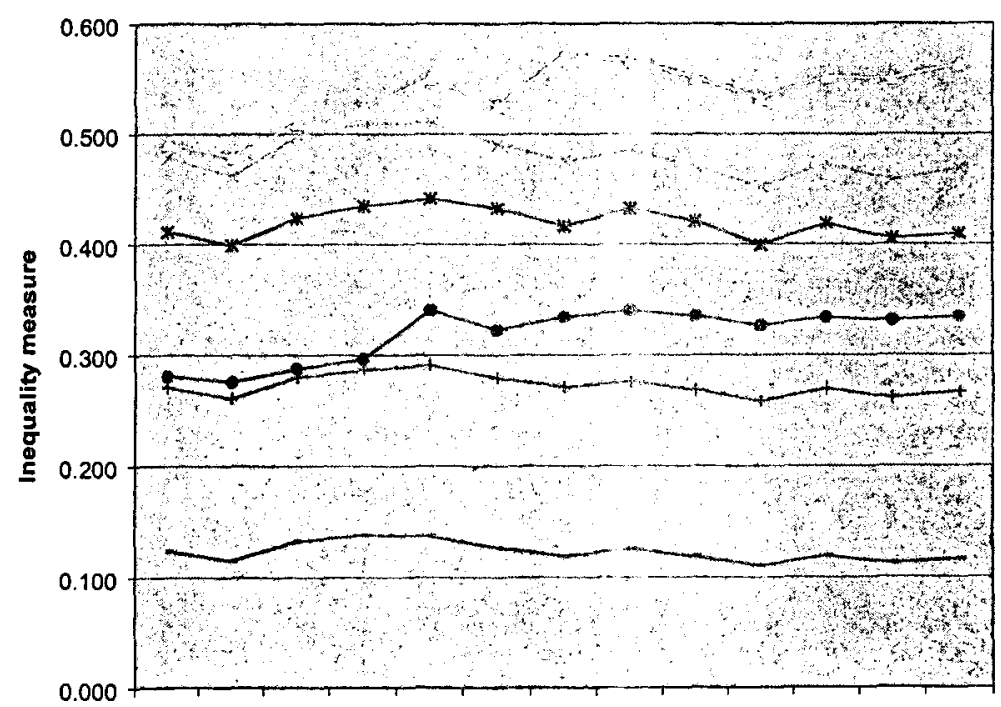

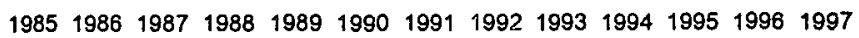

\footnotetext{
Year

Simple coefficient of variation (CVu) $\quad-\rightarrow-$ Weighted coefficient of variation $(\mathrm{CVw})$

-Weighted gini index (Gw)

$\rightarrow$ *- Relative mean Deviation (Rw)

$\rightarrow$ Unweighted gini index (Gu)
} 


\section{A4 India}

Table A4: Regional disparity trends in India

\begin{tabular}{|c|c|c|c|c|c|c|c|}
\hline Year & $\begin{array}{l}\text { Max/Min } \\
\text { (MMR) }\end{array}$ & $\begin{array}{l}\text { Simple } \\
\text { coefficient } \\
\text { of variation } \\
(\mathrm{CVu})\end{array}$ & $\begin{array}{l}\text { Weighted } \\
\text { coefficient } \\
\text { of variation } \\
(\mathrm{CVw})\end{array}$ & \begin{tabular}{|l} 
Relative \\
mean \\
Deviation \\
$(R w)$ \\
\end{tabular} & $\begin{array}{l}\text { Unweighted } \\
\text { gini index } \\
\text { (Gu) }\end{array}$ & $\begin{array}{l}\text { Weighted } \\
\text { gini index } \\
(G w)\end{array}$ & $\begin{array}{l}\text { Theil } \\
\text { index }(T)\end{array}$ \\
\hline 1980 & 2.848 & 0.312 & 0.290 & 0.221 & $\begin{array}{l}0.175 \\
\end{array}$ & 0.152 & 0.039 \\
\hline 1981 & 2.903 & 0.318 & 0.289 & 0.216 & 0.178 & 0.152 & 0.039 \\
\hline 1982 & 2.867 & 0.327 & 0.291 & 0.211 & 0.182 & 0.152 & 0.039 \\
\hline 1983 & 2.808 & 0.308 & 0.286 & 0.219 & 0.172 & 0.151 & 0.038 \\
\hline 1984 & 2.702 & 0.323 & 0.292 & 0.235 & 0.182 & 0.154 & 0.040 \\
\hline 1985 & 2.804 & 0.345 & 0.305 & 0.239 & 0.191 & 0.159 & 0.043 \\
\hline 1986 & 2.712 & 0.342 & 0.302 & 0.239 & 0.190 & 0.157 & 0,042 \\
\hline 1987 & 2.945 & 0.343 & 0.306 & 0.238 & 0.191 & 0.161 & 0.043 \\
\hline 1988 & 2.825 & 0.333 & 0.302 & 0.227 & 0.186 & 0.159 & 0.043 \\
\hline 1989 & 3.196 & 0.350 & 0.333 & 0.248 & 0.196 & 0.175 & 0.052 \\
\hline 1990 & 3.034 & 0.345 & 0.323 & 0.240 & 0.195 & 0.171 & 0.049 \\
\hline 1991 & 3.271 & 0.349 & 0.328 & 0.255 & 0.198 & 0.176 & 0.051 \\
\hline 1992 & 3.464 & 0.369 & 0.370 & 0.286 & 0.212 & 0.199 & 0.065 \\
\hline 1993 & 3.521 & 0.373 & 0.385 & 0.296 & 0.215 & 0.207 & 0.070 \\
\hline 1994 & 3.576 & 0.375 & 0.393 & 0.312 & 0.219 & 0.215 & 0.074 \\
\hline 1995 & 4.051 & 0.386 & 0.414 & 0.323 & 0.224 & 0.225 & 0.081 \\
\hline 1996 & 3.838 & 0.398 & 0.419 & 0.327 & 0.232 & 0.228 & 0.084 \\
\hline 1997 & 3.811 & 0.387 & 0.414 & 0.334 & 0.226 & 0.227 & 0.082 \\
\hline
\end{tabular}

Figure A4: Regional disparity trends in India

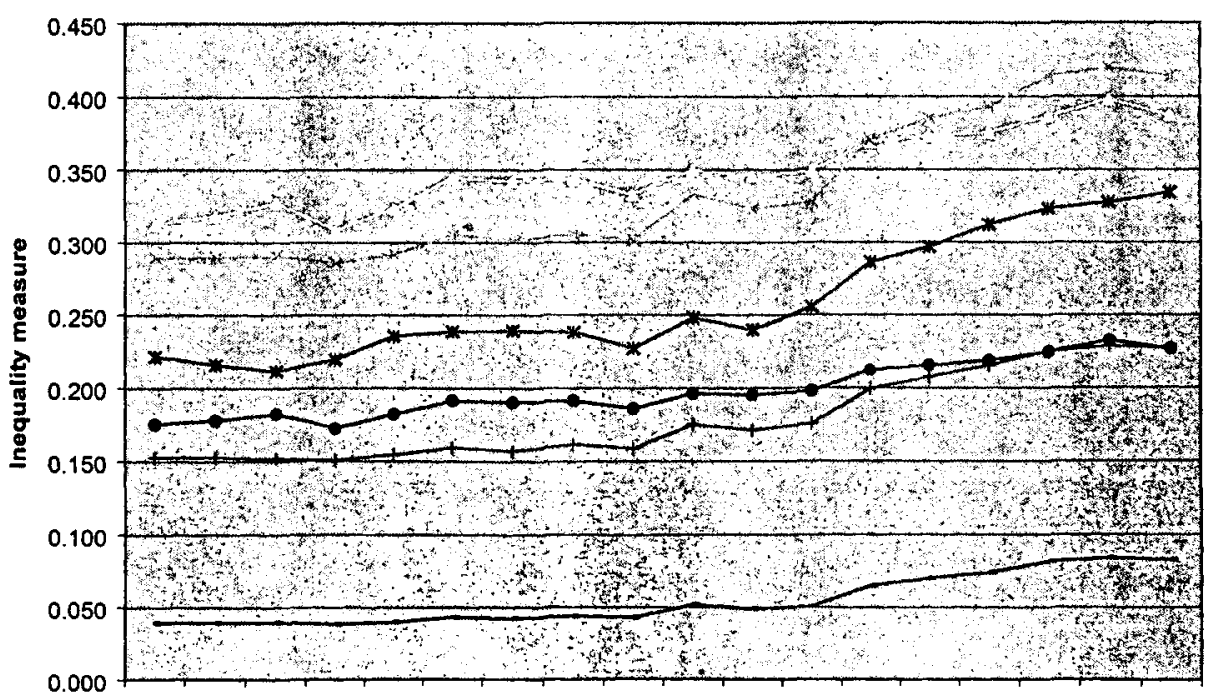

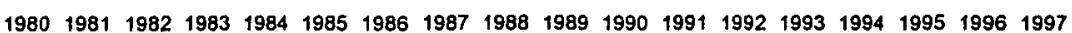

Simple coefficient of variation (CVu)

$\rightarrow-$ Unweighted gini index (Gu)

\footnotetext{
- Weighted coefficient of variation ( $\mathrm{CVw}$ )

+ Weighted gini index (Gw)

$\rightarrow$ - Relative mean Deviation (Rw)

- Theil index (T)
} 
A5 Mexico

Table A5: Regional disparity trends in Mexico

\begin{tabular}{|c|c|l|l|l|l|l|c|}
\hline & $\begin{array}{l}\text { Max/Min } \\
(\mathrm{MMR})\end{array}$ & $\begin{array}{l}\text { Simple } \\
\text { coefficient } \\
\text { of variation } \\
(\mathrm{CVu})\end{array}$ & $\begin{array}{l}\text { Weighted } \\
\text { coefficient } \\
\text { of variation } \\
(\mathrm{CVW})\end{array}$ & $\begin{array}{l}\text { Relative } \\
\text { mean } \\
\text { Deviation } \\
(\mathrm{RW})\end{array}$ & $\begin{array}{l}\text { Unweighted } \\
\text { gini index } \\
(\mathrm{Gu})\end{array}$ & $\begin{array}{l}\text { Weighted } \\
\text { gini index } \\
(\mathrm{GW})\end{array}$ & $\begin{array}{l}\text { Theil } \\
\text { index }(\mathrm{T})\end{array}$ \\
\hline 1993 & 5.591 & 0.473 & 0.572 & 0.414 & 0.251 & 0.302 & 0.137 \\
\hline 1994 & 5.583 & 0.471 & 0.573 & 0.417 & 0.250 & 0.301 & 0.137 \\
\hline 1995 & 5.479 & 0.461 & 0.559 & 0.413 & 0.246 & 0.295 & 0.130 \\
\hline 1996 & 5.618 & 0.464 & 0.561 & 0.415 & 0.249 & 0.297 & 0.131 \\
\hline 1997 & 5.793 & 0.473 & 0.571 & 0.422 & 0.253 & 0.301 & 0.136 \\
\hline 1998 & 5.874 & 0.469 & 0.566 & 0.421 & 0.251 & 0.300 & 0.134 \\
\hline
\end{tabular}

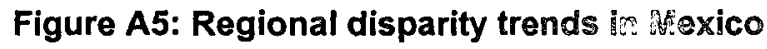

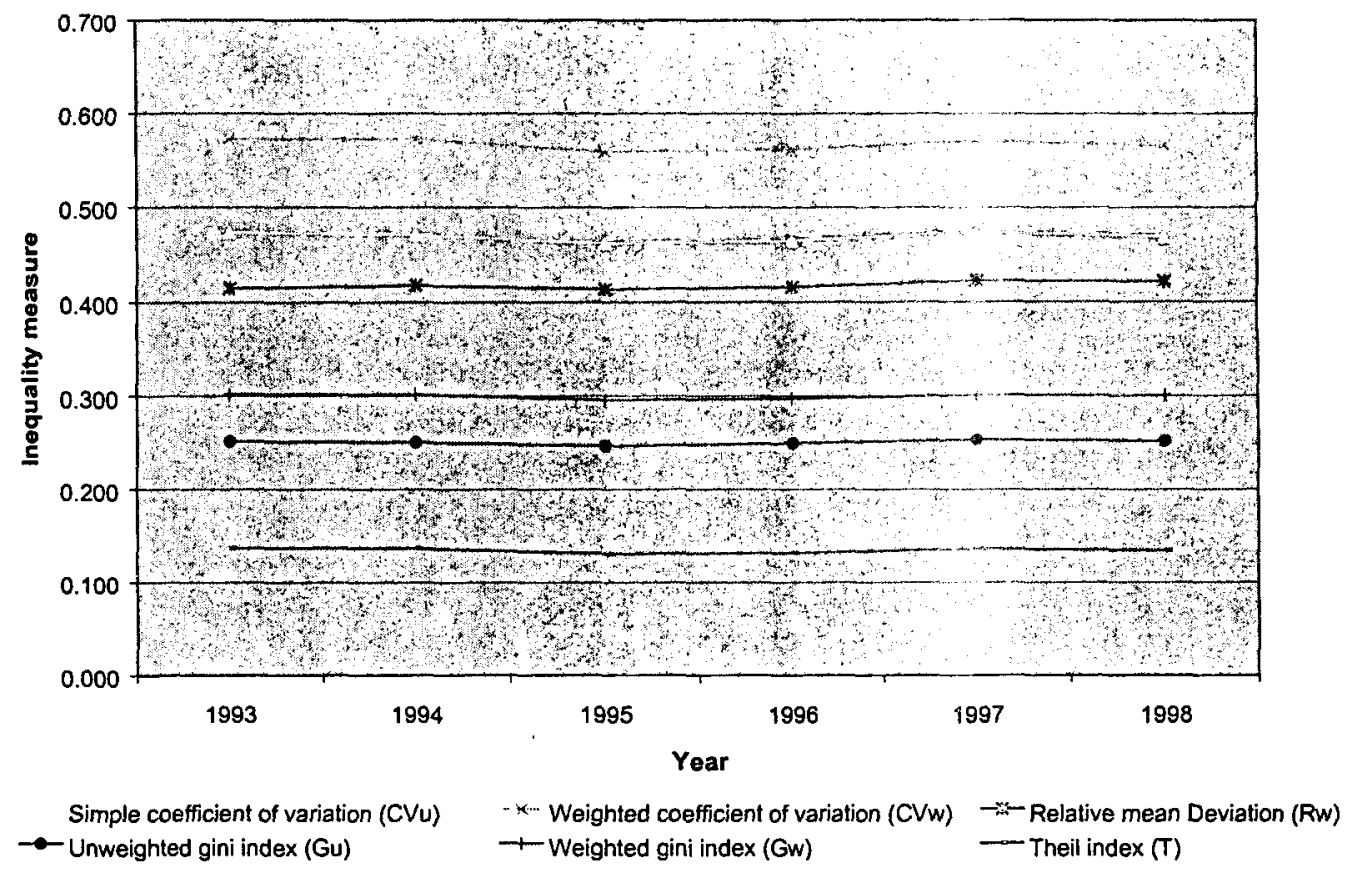




\section{A6 Pakistan}

Table A6: Regional disparity trends in Pakistan

\begin{tabular}{|c|c|l|l|l|l|l|l|}
\hline & Max/Min & $\begin{array}{l}\text { Simple } \\
\text { coefficient } \\
\text { of variation } \\
(\mathrm{CVu})\end{array}$ & $\begin{array}{l}\text { Weighted } \\
\text { coefficient } \\
\text { of variation } \\
(\mathrm{CVw})\end{array}$ & $\begin{array}{l}\text { Relative } \\
\text { mean } \\
\text { Deviation } \\
(\mathrm{Mw})\end{array}$ & $\begin{array}{l}\text { Unweighted } \\
\text { gini index } \\
(\mathrm{Gu})\end{array}$ & $\begin{array}{l}\text { Weighted } \\
\text { gini index } \\
(\mathrm{Gw})\end{array}$ & $\begin{array}{l}\text { Theil } \\
\text { index (T) }\end{array}$ \\
\hline 1990 & 1.512 & 0.215 & 0.186 & 0.125 & 0.116 & 0.081 & 0.014 \\
\hline 1991 & 1.562 & 0.213 & 0.179 & 0.118 & 0.122 & 0.082 & 0.013 \\
\hline 1992 & 1.577 & 0.214 & 0.177 & 0.115 & 0.125 & 0.083 & 0.013 \\
\hline 1993 & 1.613 & 0.216 & 0.174 & 0.109 & 0.131 & 0.083 & 0.012 \\
\hline 1994 & 1.525 & 0.191 & 0.153 & 0.096 & 0.116 & 0.073 & 0.010 \\
\hline 1995 & 1.507 & 0.186 & 0.148 & 0.094 & 0.113 & 0.071 & 0.009 \\
\hline 1996 & 1.511 & 0.188 & 0.153 & 0.096 & 0.112 & 0.073 & 0.010 \\
\hline 1997 & 1.514 & 0.186 & 0.150 & 0.094 & 0.113 & 0.072 & 0.009 \\
\hline 1998 & 1.516 & 0.183 & 0.141 & 0.095 & 0.114 & 0.069 & 0.008 \\
\hline
\end{tabular}

Figure A6: Regionai disparity trends in akistan

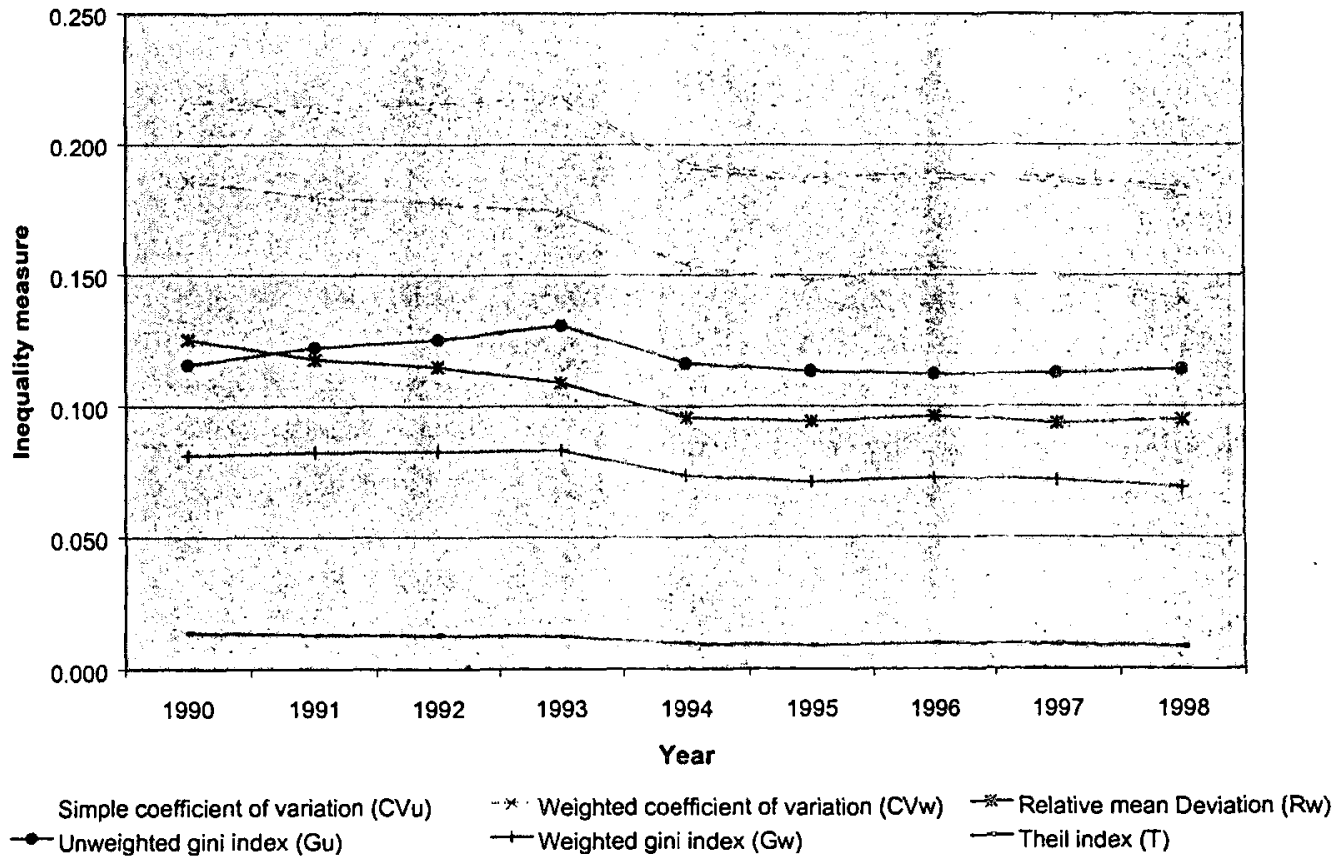


A7 Russia

Table A7: Regional disparity trends in Russia

\begin{tabular}{|c|c|l|l|l|l|l|l|}
\hline & $\begin{array}{l}\text { Max/Min } \\
(\mathrm{MMR})\end{array}$ & $\begin{array}{l}\text { Simple } \\
\text { coefficient } \\
\text { of variation } \\
(\mathrm{CVu})\end{array}$ & $\begin{array}{l}\text { Weighted } \\
\text { coefficient } \\
\text { of variation } \\
(\mathrm{CVW})\end{array}$ & $\begin{array}{l}\text { Relative } \\
\text { mean } \\
\text { Deviation } \\
(\mathrm{RW})\end{array}$ & $\begin{array}{l}\text { Unweighted } \\
\text { gini index } \\
(\mathrm{Gu})\end{array}$ & $\begin{array}{l}\text { Weighted } \\
\text { gini index } \\
(\mathrm{Gw})\end{array}$ & $\begin{array}{l}\text { Theil } \\
\text { index } \\
(\mathrm{T})\end{array}$ \\
\hline 1994 & 14.065 & 0.479 & 0.447 & 0.313 & 0.247 & 0.221 & 0.094 \\
\hline 1995 & 17.739 & 0.539 & 0.524 & 0.345 & 0.263 & 0.243 & 0.111 \\
\hline 1996 & 20.778 & 0.629 & 0.635 & 0.377 & 0.278 & 0.268 & 0.144 \\
\hline 1997 & 21.307 & 0.625 & 0.645 & 0.387 & 0.283 & 0.280 & 0.153 \\
\hline
\end{tabular}

Figure A7: Regional disparity trends in Russia

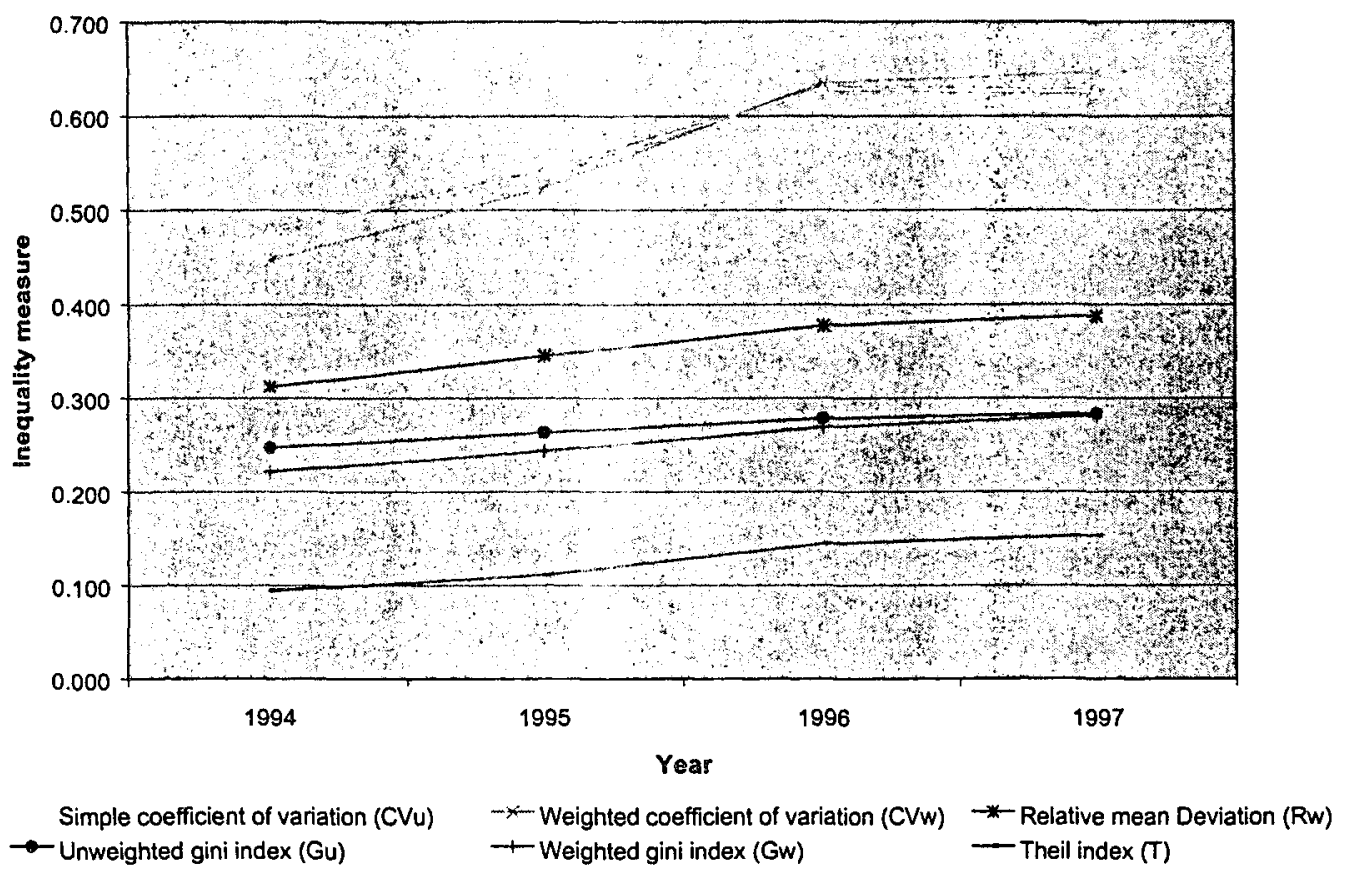




\section{A8 Chile}

Table A8: Regional disparity trends in Chile

\begin{tabular}{|c|c|c|c|c|c|c|c|}
\hline Year & $\begin{array}{l}\text { Max/Min } \\
\text { (MMR) }\end{array}$ & $\begin{array}{l}\text { Simple } \\
\text { coefficient } \\
\text { of variation } \\
(\mathrm{CVu})\end{array}$ & $\begin{array}{l}\text { Weighted } \\
\text { coefficient } \\
\text { of variation } \\
\text { (CVw) }\end{array}$ & $\begin{array}{l}\text { Relative } \\
\text { mean } \\
\text { Deviation } \\
(\mathrm{Rw}) \\
\end{array}$ & $\begin{array}{l}\text { Unweighted } \\
\text { gini index } \\
\text { (Gu) }\end{array}$ & $\begin{array}{l}\text { Weighted } \\
\text { gini index } \\
(\mathrm{Gw})\end{array}$ & $\begin{array}{l}\text { Theil } \\
\text { index } \\
(\mathrm{T}) \\
\end{array}$ \\
\hline 1987 & 6.841 & $\begin{array}{l}0.599 \\
\end{array}$ & 0.377 & 0.250 & $\begin{array}{l}0.313 \\
\end{array}$ & 0.176 & $\begin{array}{l}0.066 \\
\end{array}$ \\
\hline 1990 & 6.173 & 0.580 & 0.372 & 0.245 & 0.298 & 0.172 & 0.062 \\
\hline 1992 & 5.959 & 0.528 & 0.359 & 0.258 & 0.282 & 0.174 & 0.060 \\
\hline 1994 & 5.696 & 0.486 & 0.334 & 0.243 & 0.267 & 0.165 & 0.052 \\
\hline
\end{tabular}

Figure A8: Regional disparity trends in Chile

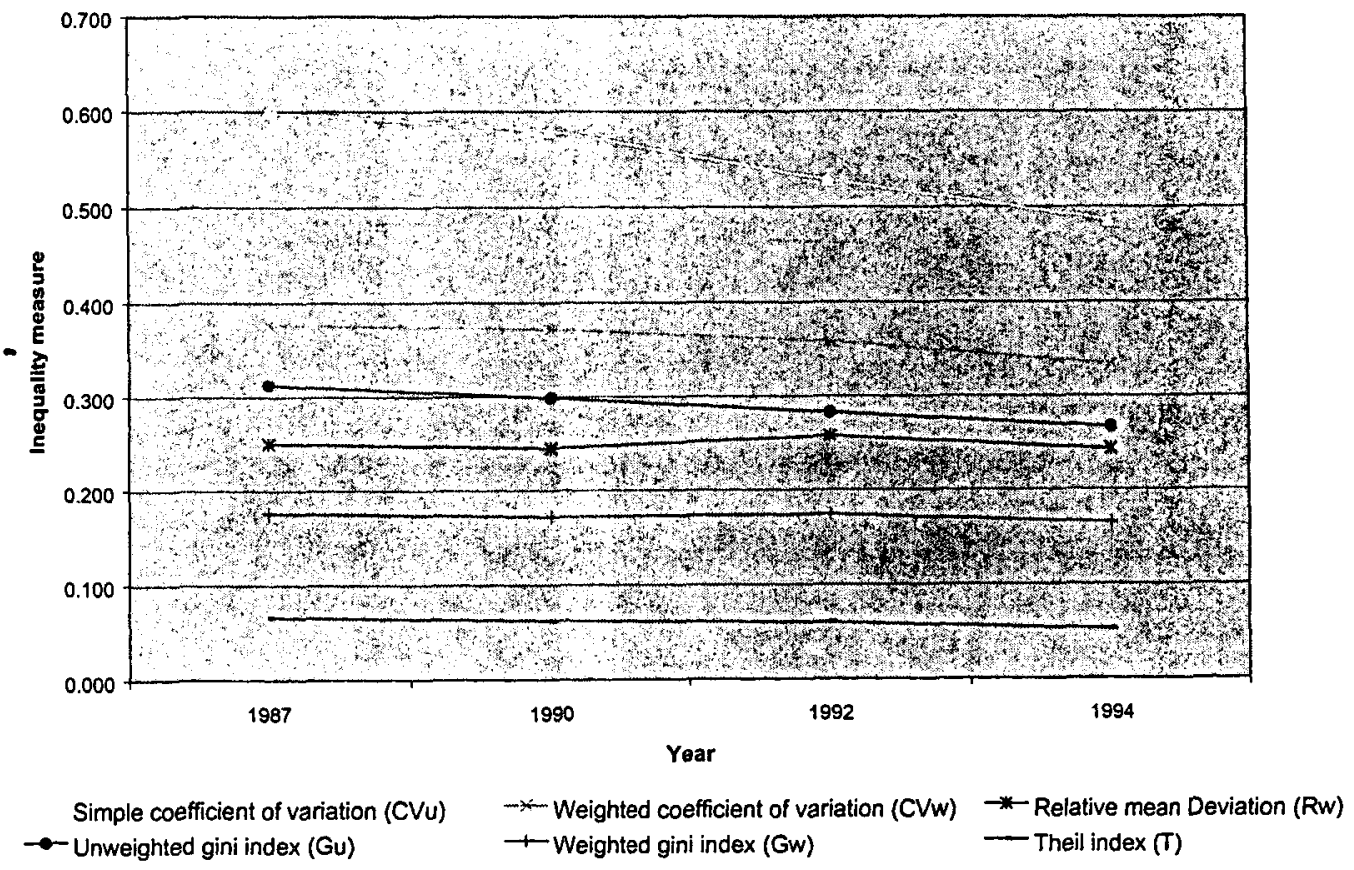




\section{A9 China}

Table A9.1: Regional disparity trends in China

\begin{tabular}{|c|c|c|c|c|c|c|c|}
\hline Year & $\begin{array}{l}\text { Max/Min } \\
\text { (MMR) }\end{array}$ & $\begin{array}{l}\text { Simple } \\
\text { coefficient } \\
\text { of variation } \\
(\mathrm{CVu})\end{array}$ & $\begin{array}{l}\text { Weighted } \\
\text { coefficient } \\
\text { of variation } \\
(\mathrm{CVw})\end{array}$ & $\begin{array}{l}\text { Relative } \\
\text { mean } \\
\text { Deviation } \\
(\mathrm{Rw})\end{array}$ & $\begin{array}{l}\text { Unweighted } \\
\text { gini index } \\
\text { (Gu) }\end{array}$ & $\begin{array}{l}\text { Weighted } \\
\text { gini index } \\
(\mathrm{Gw})\end{array}$ & $\begin{array}{l}\text { Theil } \\
\text { index (T) }\end{array}$ \\
\hline 1978 & 14.311 & 0.994 & 1.673 & 0.814 & 0.412 & 0.246 & 0.167 \\
\hline 1979 & 12.499 & 0.938 & 1.501 & 0.765 & 0.375 & 0.235 & 0.152 \\
\hline 1980 & 12.432 & 0.923 & 1.471 & 0.759 & 0.394 & 0.233 & 0.146 \\
\hline 1981 & 12.442 & 0.891 & 1.403 & 0.741 & 0.362 & 0.226 & 0.138 \\
\hline 1982 & 10.254 & 0.844 & 1.298 & 0.710 & 0.350 & 0.219 & 0.127 \\
\hline 1983 & 9.739 & 0.809 & 1.197 & 0.667 & 0.346 & 0.218 & 0.121 \\
\hline 1984 & 8.739 & 0.778 & 1.135 & 0.677 & 0.342 & 0.219 & 0.117 \\
\hline 1985 & 9.131 & 0.757 & 1.086 & 0.606 & 0.337 & 0.214 & 0.104 \\
\hline 1986 & 8.527 & 0.729 & 1.018 & 0.586 & 0.334 & 0.218 & 0.102 \\
\hline 1987 & 7.991 & 0.698 & 0.950 & 0.566 & 0.329 & 0.219 & 0.098 \\
\hline 1988 & 7.630 & 0.675 & 0.905 & 0.570 & 0.324 & 0.222 & 0.097 \\
\hline 1989 & 7.321 & 0.652 & 0.882 & 0.580 & 0.317 & 0.222 & 0.094 \\
\hline 1990 & 7.309 & 0.644 & 0.882 & 0.581 & 0.311 & 0.213 & 0.089 \\
\hline 1991 & 7.483 & 0.683 & 0.976 & 0.662 & 0.334 & 0.236 & 0.106 \\
\hline 1992 & 8.563 & 0.699 & 0.972 & 0.653 & 0.339 & 0.239 & 0.109 \\
\hline 1993 & 9.352 & 0.682 & 0.960 & 0.681 & 0.342 & 0.251 & 0.115 \\
\hline 1994 & 9.648 & 0.635 & 0.874 & 0.663 & 0.332 & 0.248 & 0.108 \\
\hline 1995 & 9.690 & 0.618 & 0.822 & 0.626 & 0.326 & 0.244 & 0.103 \\
\hline
\end{tabular}

Table A9.2: Regional disparity trends in China (new)

\begin{tabular}{|c|c|l|l|l|l|l|l|}
\hline & Max/Min & $\begin{array}{l}\text { Simple } \\
\text { coefficient } \\
\text { of variation } \\
\text { (CVu) }\end{array}$ & $\begin{array}{l}\text { Weighted } \\
\text { coefficient } \\
\text { of variation } \\
(\mathrm{CVw})\end{array}$ & $\begin{array}{l}\text { Relative } \\
\text { mean } \\
\text { Deviation } \\
(\mathrm{R} w)\end{array}$ & $\begin{array}{l}\text { Unweighted } \\
\text { gini index } \\
(\mathrm{Gu})\end{array}$ & $\begin{array}{l}\text { Weighted } \\
\text { gini index } \\
(\mathrm{Gw})\end{array}$ & $\begin{array}{l}\text { Theil } \\
\text { index (T) }\end{array}$ \\
\hline 1993 & 9.323 & 0.664 & 0.931 & 0.680 & 0.339 & 0.252 & 0.113 \\
\hline 1994 & 9.790 & 0.662 & 0.920 & 0.687 & 0.343 & 0.255 & 0.114 \\
\hline 1995 & 10.223 & 0.669 & 0.900 & 0.664 & 0.345 & 0.253 & 0.112 \\
\hline 1996 & 11.022 & 0.672 & 0.894 & 0.653 & 0.343 & 0.247 & 0.108 \\
\hline 1997 & 11.625 & 0.692 & 0.924 & 0.666 & 0.351 & 0.250 & 0.111 \\
\hline 1998 & 12.183 & 0.709 & 0.952 & 0.679 & 0.357 & 0.254 & 0.115 \\
\hline 1999 & 12.507 & 0.730 & 0.987 & 0.694 & 0.365 & 0.264 & 0.125 \\
\hline
\end{tabular}


Figure A9.1: Regional disparity trends in China

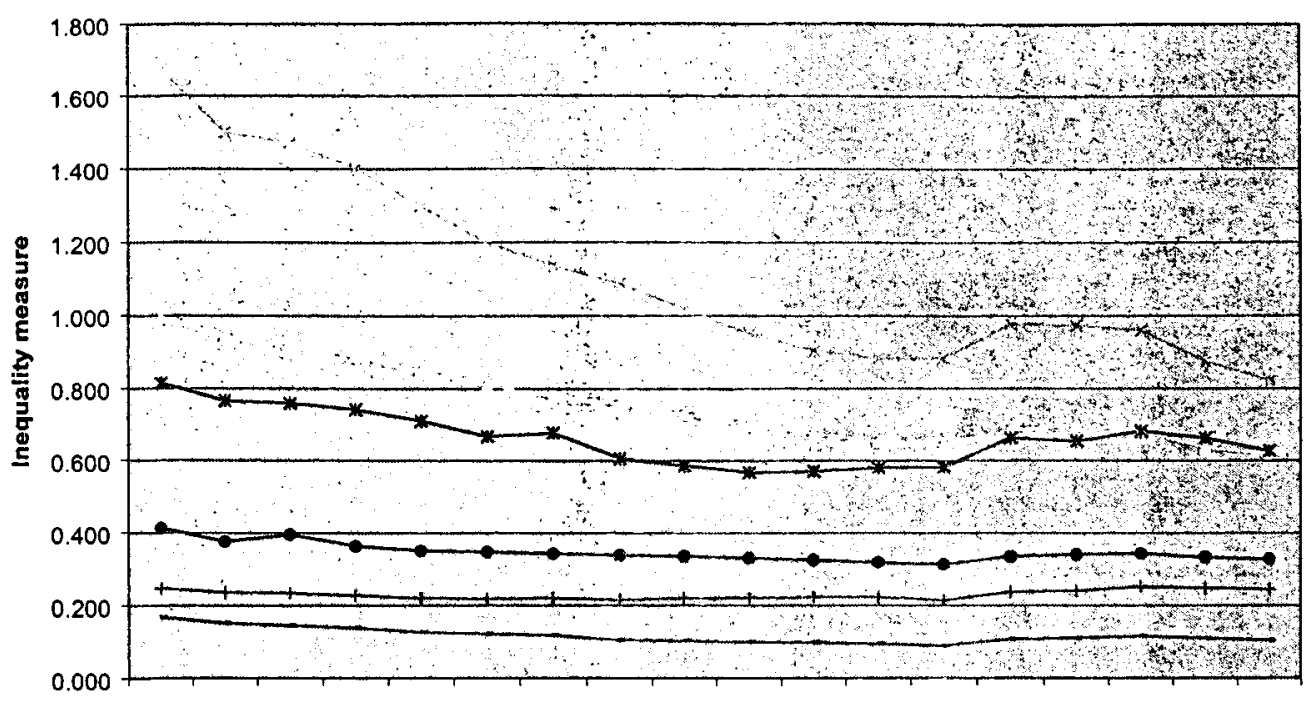

197819791980198119821983198419851986198719881989199019911992199319941995

Year

Simple coefficient of variation (CVu) $\quad \rightarrow-$ Weighted coefficient of variation $(C V w) \quad$ * Relative mean Deviation (Rw)

\section{Figure A9.2: Regional disparity trends in China (new)}

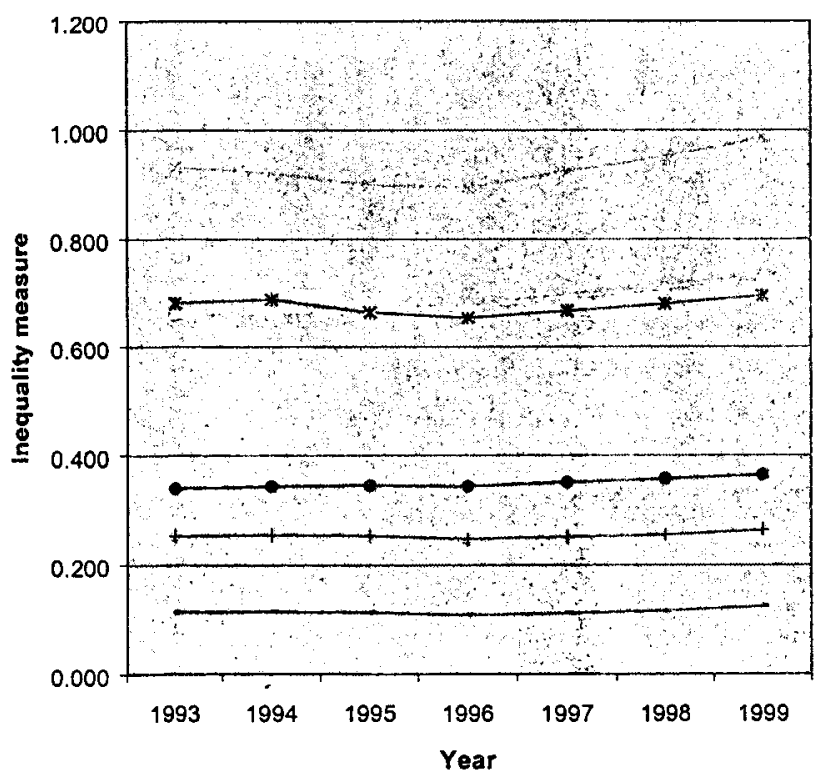

\footnotetext{
Simple coefficient of variation ( $\mathrm{CVu}$ )

$\rightarrow$ Weighted coefficient of variation (CVw)

$\rightarrow$-Relative mean Deviation (Rw)

- Unweighted gini index (Gu)

$\rightarrow$ Weighted gini index (Gw)

-Theil index $(\mathrm{T})$
} 


\section{A10 Indonesia}

Table A10: Regional disparity trends in Indonesia

\begin{tabular}{|c|l|l|l|l|l|l|l|}
\hline & Simple & $\begin{array}{l}\text { Weighted } \\
\text { coefficient } \\
\text { of variation } \\
\text { coefficient } \\
\text { of variation } \\
\text { (CVW) }\end{array}$ & $\begin{array}{l}\text { Relative } \\
\text { mean } \\
\text { Deviation } \\
\text { (Rw) }\end{array}$ & $\begin{array}{l}\text { Unweighted } \\
\text { gini index } \\
\text { (Gu) }\end{array}$ & $\begin{array}{l}\text { Weighted } \\
\text { gini index } \\
\text { (Gw) }\end{array}$ & $\begin{array}{l}\text { Theil } \\
\text { index } \\
(T)\end{array}$ \\
\hline 1983 & 22.5847013 & 1.278928412 & 1.045353512 & 0.524525937 & 0.498090815 & 0.327522886 & 0.291769 \\
\hline 1984 & 23.5151753 & 1.259632203 & 0.986509155 & 0.510085267 & 0.495885587 & 0.321188141 & 0.271792 \\
\hline 1985 & 23.456313 & 1.225443527 & 0.92956683 & 0.486817897 & 0.484608404 & 0.308012365 & 0.24848 \\
\hline 1986 & 22.1419003 & 1.197745028 & 0.914691083 & 0.478128349 & 0.476612204 & 0.30382535 & 0.242335 \\
\hline 1987 & 20.2619614 & 1.177594199 & 0.912915883 & 0.475944777 & 0.472133642 & 0.303754213 & 0.242334 \\
\hline 1988 & 18.3373762 & 1.121082092 & 0.870920124 & 0.461382878 & 0.459062777 & 0.298613708 & 0.227941 \\
\hline 1989 & 17.6853777 & 1.08754064 & 0.84622963 & 0.456606685 & 0.452021238 & 0.297733037 & 0.220859 \\
\hline 1990 & 16.5142032 & 1.004046548 & 0.786066848 & 0.439602924 & 0.426054577 & 0.283251414 & 0.200953 \\
\hline 1991 & 15.6473778 & 0.969170008 & 0.758619413 & 0.429445677 & 0.416552159 & 0.278166675 & 0.191102 \\
\hline 1992 & 14.691083 & 0.935834451 & 0.730877648 & 0.419450668 & 0.406777244 & 0.272740377 & 0.180907 \\
\hline 1993 & 12.0836414 & 0.854120074 & 0.724461673 & 0.408882556 & 0.386250383 & 0.27373039 & 0.179321 \\
\hline 1994 & 12.0691998 & 0.856486923 & 0.725320312 & 0.40647926 & 0.384708797 & 0.273958672 & 0.179087 \\
\hline 1995 & 11.3204885 & 0.832031106 & 0.714357197 & 0.402331558 & 0.378927738 & 0.272279979 & 0.175069 \\
\hline 1996 & 11.2585855 & 0.829683054 & 0.715114513 & 0.401136398 & 0.378888842 & 0.272752728 & 0.175245 \\
\hline 1997 & 11.0479421 & 0.826971859 & 0.71556985 & 0.400533444 & 0.378321467 & 0.274007153 & 0.175501 \\
\hline 1998 & 11.436067 & 0.831810458 & 0.721908624 & 0.415908131 & 0.381198154 & 0.277069913 & 0.177892 \\
\hline
\end{tabular}

Figure A10: Regional inequality trends in Indonesia

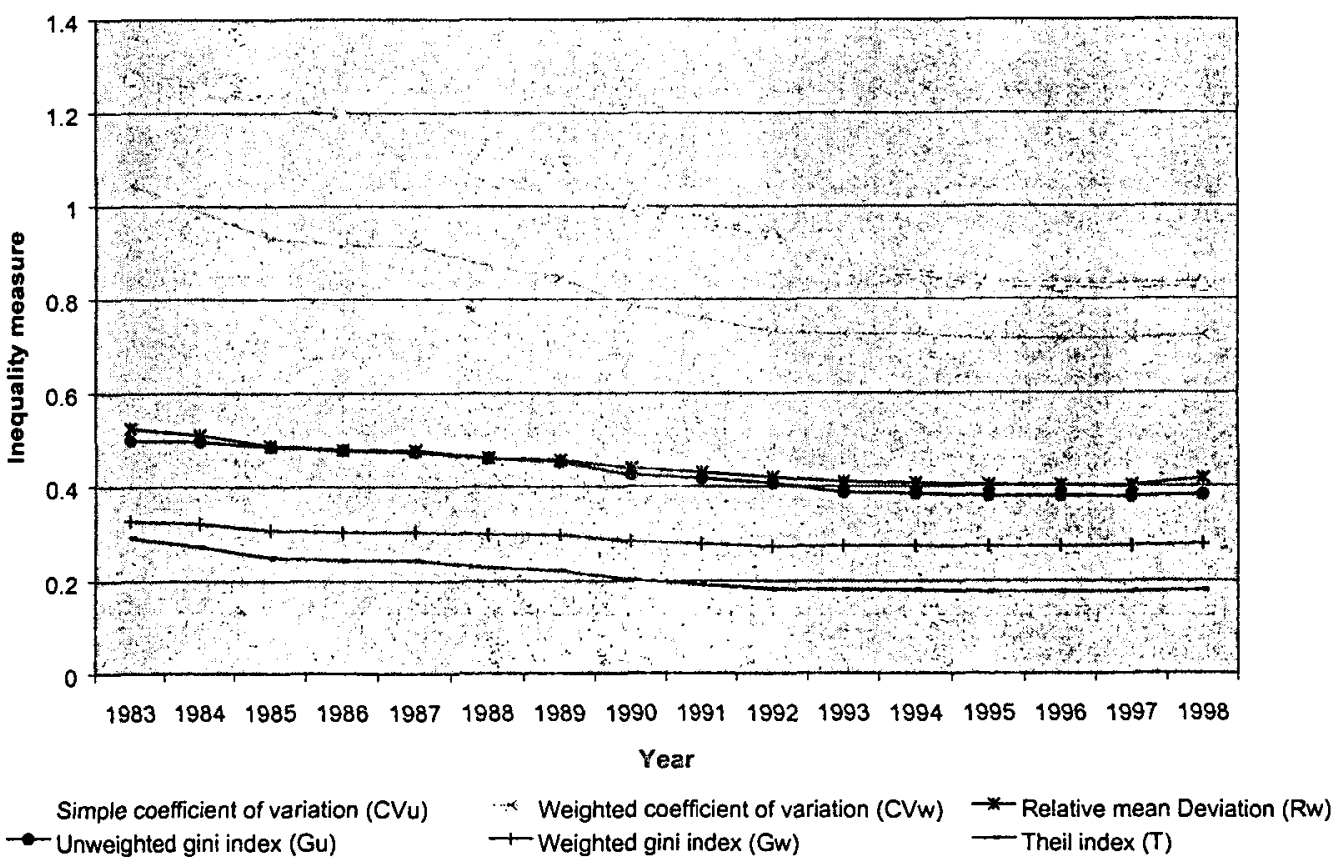




\section{A11 Philippines}

Table A11: Regional disparity trends in Philippines

\begin{tabular}{|c|c|l|l|l|l|l|l|}
\hline & Max/Min & $\begin{array}{l}\text { Simple } \\
\text { coefficient } \\
\text { of variation } \\
\text { (CVu) }\end{array}$ & $\begin{array}{l}\text { Weighted } \\
\text { coefficient } \\
\text { of variation } \\
\text { (CVW) }\end{array}$ & $\begin{array}{l}\text { Relative } \\
\text { mean } \\
\text { Deviation } \\
(\text { Rw })\end{array}$ & $\begin{array}{l}\text { Unweighted } \\
\text { gini index } \\
\text { (Gu) }\end{array}$ & $\begin{array}{l}\text { Weighted } \\
\text { gini index } \\
\text { (Gw) }\end{array}$ & $\begin{array}{l}\text { Theil } \\
\text { index (T) }\end{array}$ \\
\hline 1982 & 5.366 & 0.506 & 0.550 & 0.365 & 0.216 & 0.268 & 0.166 \\
\hline 1983 & 5.362 & 0.520 & 0.568 & 0.368 & 0.217 & 0.271 & 0.172 \\
\hline 1984 & 4.803 & 0.485 & 0.533 & 0.352 & 0.203 & 0.255 & 0.158 \\
\hline 1985 & 4.534 & 0.465 & 0.511 & 0.338 & 0.197 & 0.246 & 0.150 \\
\hline 1986 & 4.669 & 0.463 & 0.507 & 0.337 & 0.198 & 0.246 & 0.149 \\
\hline 1987 & 4.928 & 0.494 & 0.531 & 0.360 & 0.248 & 0.262 & 0.146 \\
\hline 1988 & 4.976 & 0.504 & 0.544 & 0.362 & 0.287 & 0.265 & 0.150 \\
\hline 1989 & 5.083 & 0.518 & 0.559 & 0.367 & 0.290 & 0.270 & 0.156 \\
\hline 1990 & 5.005 & 0.515 & 0.556 & 0.365 & 0.285 & 0.267 & 0.154 \\
\hline 1991 & 4.910 & 0.511 & 0.552 & 0.364 & 0.284 & 0.266 & 0.152 \\
\hline 1992 & 4.689 & 0.494 & 0.526 & 0.348 & 0.280 & 0.258 & 0.144 \\
\hline 1993 & 6.868 & 0.517 & 0.513 & 0.351 & 0.301 & 0.255 & 0.117 \\
\hline 1994 & 6.627 & 0.515 & 0.513 & 0.352 & 0.302 & 0.255 & 0.116 \\
\hline 1995 & 6.431 & 0.512 & 0.513 & 0.353 & 0.299 & 0.254 & 0.116 \\
\hline 1996 & 6.516 & 0.525 & 0.524 & 0.362 & 0.305 & 0.259 & 0.120 \\
\hline 1997 & 6.653 & 0.530 & 0.532 & 0.367 & 0.307 & 0.261 & 0.123 \\
\hline 1998 & 6.760 & 0.536 & 0.537 & 0.369 & 0.311 & 0.262 & 0.125 \\
\hline
\end{tabular}

Figure A11: Regional disparity trends in Philippines

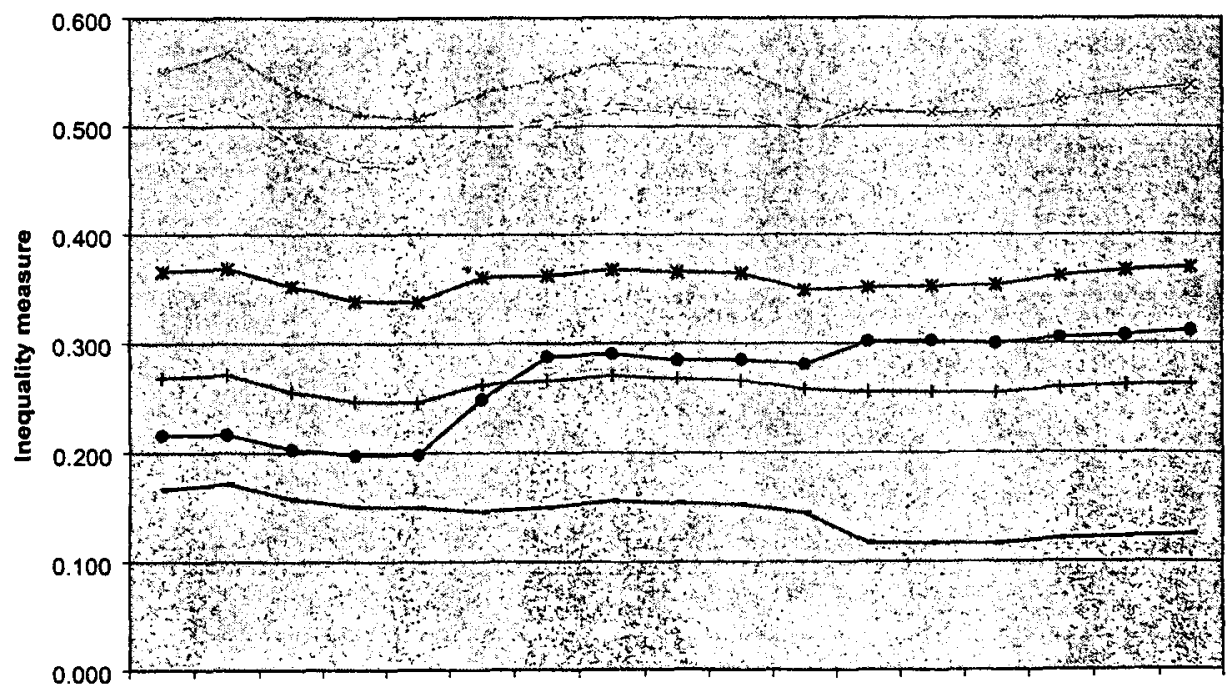

19821983198419851986198719881989199019911992199319941995199619971998

Year

$\begin{array}{lll}\text { Simple coefficient of variation }(\mathrm{CVu}) & - \text { Weighted coefficient of variation }(\mathrm{CVW}) & \rightarrow \text { - Relative mean Deviation }(\mathrm{Rw}) \\ \text { Unweighted gini index }(\mathrm{Gu}) & \text {-Weighted gini index }(\mathrm{Gw}) & \text { - Theil index }(\mathrm{T})\end{array}$ 


\section{A12 Romania}

Table A12: Regional disparity trends in Romania

\begin{tabular}{|c|c|l|l|l|l|l|l|}
\hline Year & $\begin{array}{l}\text { Max/Min } \\
(\mathrm{MMR})\end{array}$ & $\begin{array}{l}\text { Simple } \\
\text { coefficient } \\
\text { of variation } \\
(\mathrm{CVu})\end{array}$ & $\begin{array}{l}\text { Weighted } \\
\text { coefficient } \\
\text { of variation } \\
(\mathrm{CVw})\end{array}$ & $\begin{array}{l}\text { Relative } \\
\text { mean } \\
\text { Deviation } \\
(\mathrm{Rw})\end{array}$ & $\begin{array}{l}\text { Unweighted } \\
\text { gini index } \\
(\mathrm{Gu})\end{array}$ & $\begin{array}{l}\text { Weighted } \\
\text { gini index } \\
(\mathrm{Gw})\end{array}$ & $\begin{array}{l}\text { Theil } \\
\text { index } \\
(\mathrm{T})\end{array}$ \\
\hline 1993 & 1.693 & 0.171 & 0.156 & 0.111 & 0.095 & 0.081 & 0.010 \\
\hline 1996 & 1.783 & 0.189 & 0.174 & 0.132 & 0.106 & 0.090 & 0.012 \\
\hline
\end{tabular}

Figure A12: Regional disparity trends in Romania

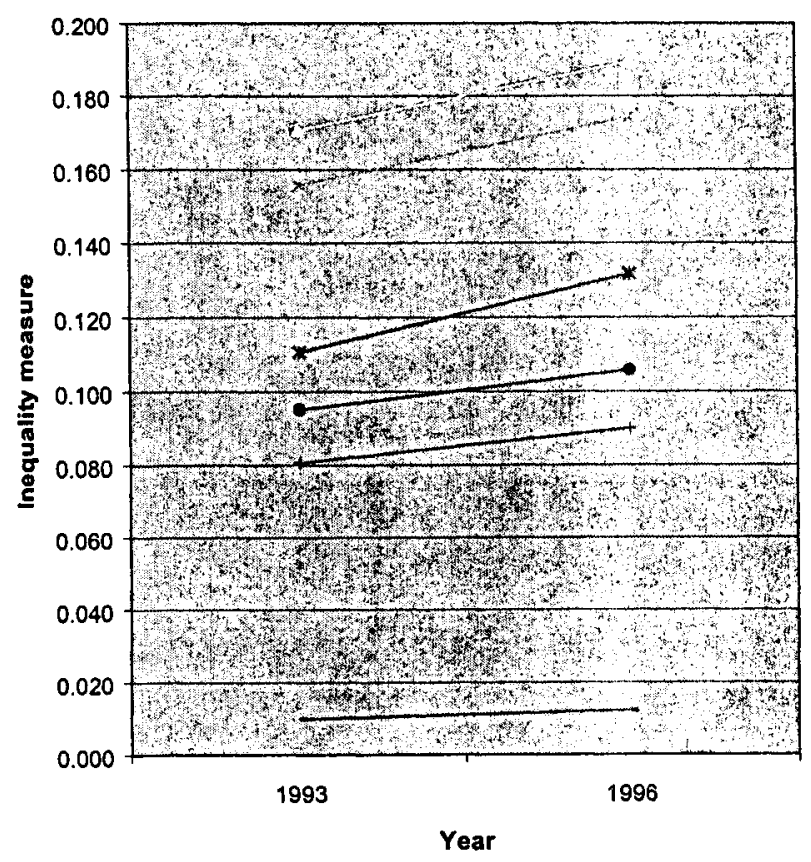

\footnotetext{
Simple coefficient of variation ( $\mathrm{CVu}$ )

- Weighted coefficient of variation ( $\mathrm{CVw}$ )

$\rightarrow$-Relative mean Deviation (Rw)

$\infty$ Unweighted gini index (Gu)

+ Weighted gini index (Gw)

- Theil index $(T)$
} 


\section{A13 Sri Lanka}

Table A13: Regional disparity trends in Sri Lanka

\begin{tabular}{|c|c|l|l|l|l|l|l|}
\hline & $\begin{array}{l}\text { Max/Min } \\
(\mathrm{MMR})\end{array}$ & $\begin{array}{l}\text { Simple } \\
\text { coefficient } \\
\text { of variation } \\
(\mathrm{CVu})\end{array}$ & $\begin{array}{l}\text { Weighted } \\
\text { coefficient } \\
\text { of variation } \\
(\mathrm{CV} \text { w) }\end{array}$ & $\begin{array}{l}\text { Reiative } \\
\text { mean } \\
\text { Deviation } \\
(\mathrm{Rw})\end{array}$ & $\begin{array}{l}\text { Unweighted } \\
\text { gini index } \\
(\mathrm{Gu})\end{array}$ & $\begin{array}{l}\text { Weighted } \\
\text { gini index } \\
(\mathrm{Gw})\end{array}$ & $\begin{array}{l}\text { Theil } \\
\text { index } \\
(\mathrm{T})\end{array}$ \\
\hline 1990 & 2.506 & 0.354 & 0.376 & 0.340 & 0.209 & 0.205 & 0.069 \\
\hline 1991 & 2.496 & 0.321 & 0.358 & 0.321 & 0.186 & 0.196 & 0.063 \\
\hline 1992 & 2.769 & 0.345 & 0.390 & 0.344 & 0.200 & 0.214 & 0.074 \\
\hline 1993 & 2.915 & 0.349 & 0.399 & 0.351 & 0.205 & 0.220 & 0.078 \\
\hline 1994 & 3.121 & 0.374 & 0.426 & 0.375 & 0.219 & 0.235 & 0.090 \\
\hline 1995 & 3.362 & 0.394 & 0.452 & 0.397 & 0.230 & 0.249 & 0.101 \\
\hline
\end{tabular}

Figure A13: Regional disparity trends in Sri Lanka

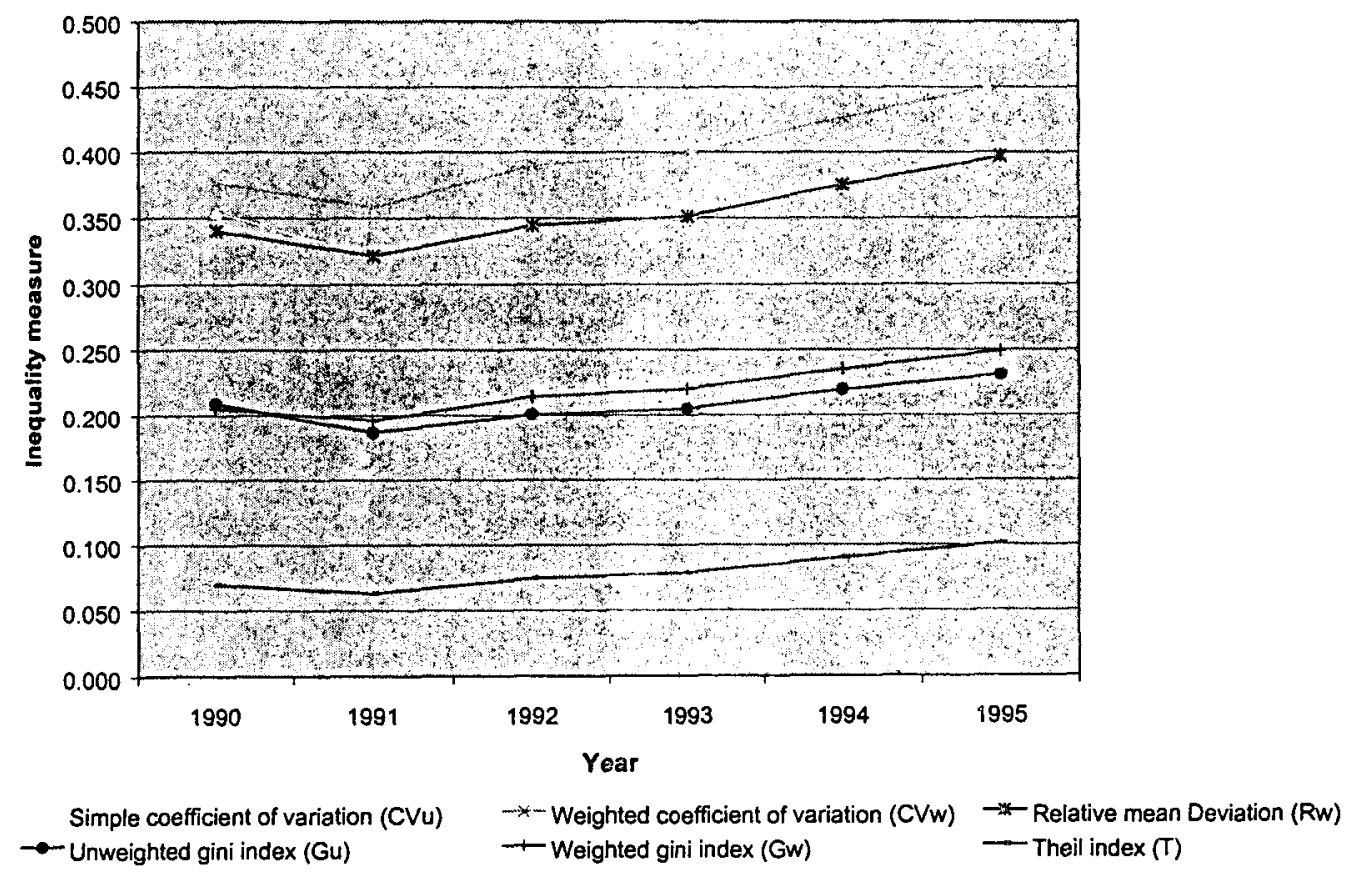




\section{A14 Thailand}

Table A14 : Regional disparity trends in Thailand

\begin{tabular}{|c|c|l|l|l|l|l|l|}
\hline & Max/Min & $\begin{array}{l}\text { Simple } \\
\text { coefficient } \\
\text { of variation } \\
(\mathrm{CVu})\end{array}$ & $\begin{array}{l}\text { Weighted } \\
\text { coefficient } \\
\text { of variation } \\
(\mathrm{CVw})\end{array}$ & $\begin{array}{l}\text { Relative } \\
\text { mean } \\
\text { Deviation } \\
\text { (Rw) }\end{array}$ & $\begin{array}{l}\text { Unweighted } \\
\text { gini index } \\
(\mathrm{Gu})\end{array}$ & $\begin{array}{l}\text { Weighted } \\
\text { gini index } \\
(\mathrm{Gw})\end{array}$ & $\begin{array}{l}\text { Theil } \\
\text { index }(\mathrm{T})\end{array}$ \\
\hline 1991 & 9.320 & 0.880 & 1.002 & 0.765 & 0.451 & 0.457 & 0.389 \\
\hline 1992 & 9.077 & 0.865 & 0.986 & 0.756 & 0.446 & 0.452 & 0.379 \\
\hline 1993 & 9.774 & 0.894 & 1.020 & 0.789 & 0.463 & 0.468 & 0.406 \\
\hline 1994 & 9.262 & 0.861 & 0.989 & 0.772 & 0.454 & 0.459 & 0.387 \\
\hline 1995 & 8.696 & 0.834 & 0.959 & 0.754 & 0.443 & 0.449 & 0.368 \\
\hline 1996 & 8.529 & 0.816 & 0.944 & 0.751 & 0.442 & 0.447 & 0.361 \\
\hline 1997 & 8.273 & 0.797 & 0.925 & 0.745 & 0.438 & 0.442 & 0.351 \\
\hline
\end{tabular}

Figure A14: Regional disparity trends in Thailand

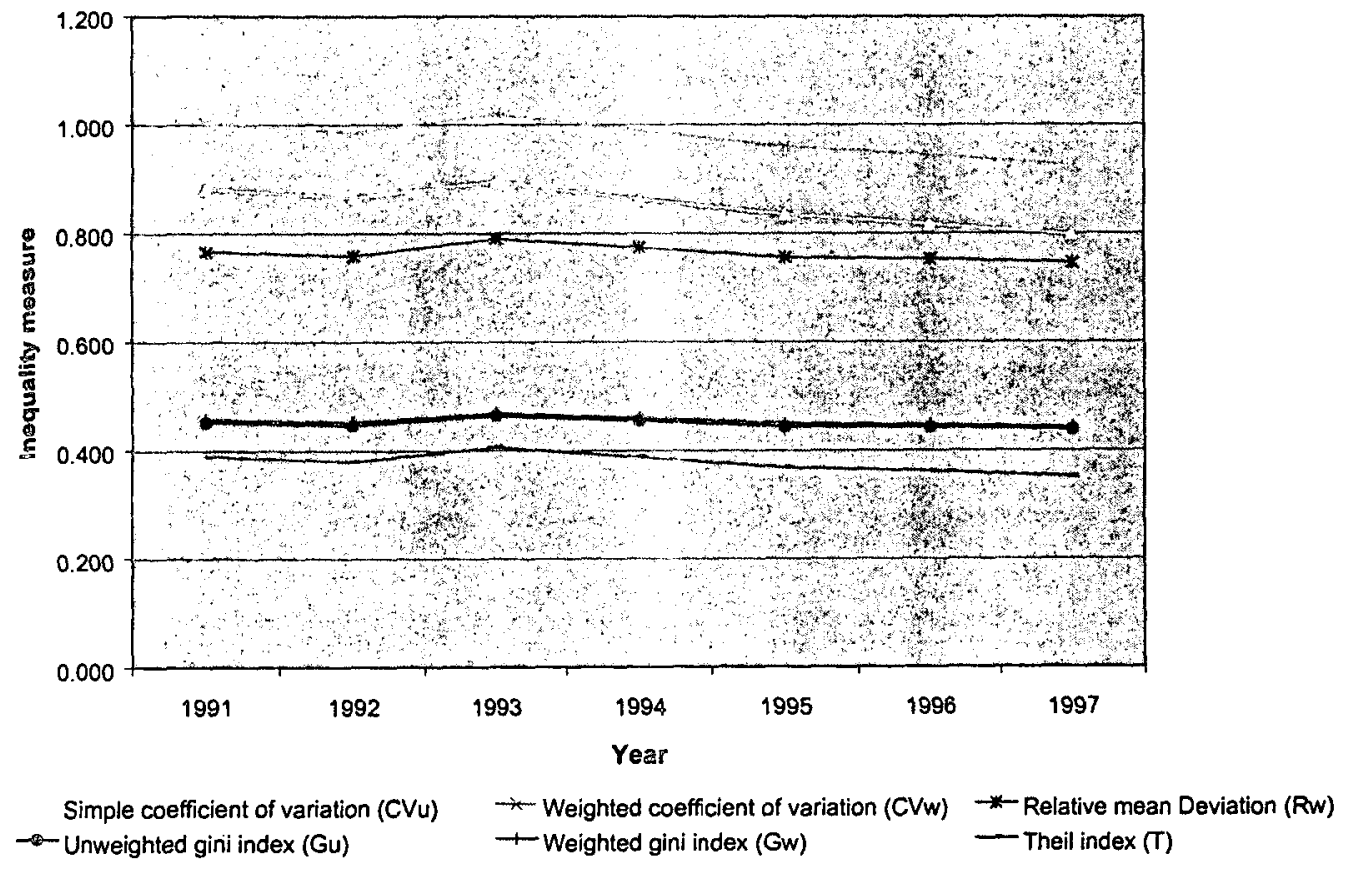




\section{A15 Uzbekistan}

Table A15: Regional disparity trends in Uzbekistan

\begin{tabular}{|c|c|l|l|l|l|l|c|}
\hline & & $\begin{array}{l}\text { Simple } \\
\text { coefficient } \\
\text { of variation } \\
(\mathrm{CVu})\end{array}$ & $\begin{array}{l}\text { Weighted } \\
\text { coefficient } \\
\text { of variation } \\
(\mathrm{CVW})\end{array}$ & $\begin{array}{l}\text { Relative } \\
\text { mean } \\
\text { Deviation } \\
(\mathrm{RW})\end{array}$ & $\begin{array}{l}\text { Unweighted } \\
\text { gini index } \\
(\mathrm{Gu})\end{array}$ & $\begin{array}{l}\text { Weighted } \\
\text { gini index } \\
(\mathrm{GW})\end{array}$ & $\begin{array}{l}\text { Theil } \\
\text { index (T) }\end{array}$ \\
\hline 1996 & 2.840 & 0.336 & 0.341 & 0.234 & 0.149 & 0.165 & 0.051 \\
\hline 1997 & 3.047 & 0.353 & 0.355 & 0.238 & 0.155 & 0.170 & 0.054 \\
\hline 1998 & 2.991 & 0.321 & 0.320 & 0.218 & 0.147 & 0.159 & 0.046 \\
\hline 1999 & 2.779 & 0.304 & 0.301 & 0.206 & 0.142 & 0.152 & 0.041 \\
\hline
\end{tabular}

Figure A15: Regional disparity trends in Uzbekistan

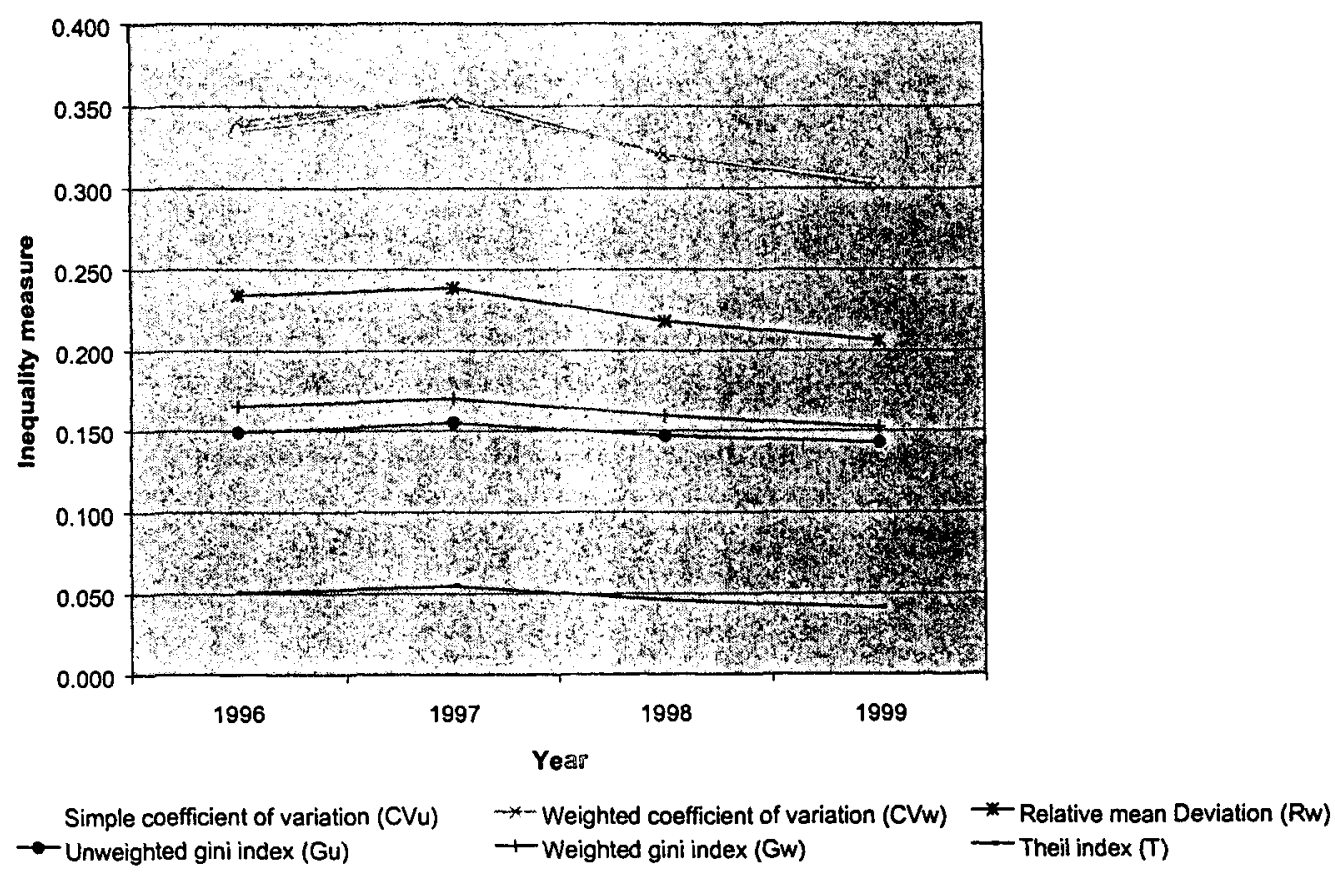


Table A16: Regional disparity trends in Vietnam

\begin{tabular}{|c|c|l|l|l|l|l|l|}
\hline & Max/Min & $\begin{array}{l}\text { Simple } \\
\text { coefficient } \\
\text { of variation } \\
(\mathrm{CVu})\end{array}$ & $\begin{array}{l}\text { Weighted } \\
\text { coefficient } \\
\text { of variation } \\
(\mathrm{CVW})\end{array}$ & $\begin{array}{l}\text { Relative } \\
\text { mean } \\
\text { Deviation } \\
(\mathrm{MW})\end{array}$ & $\begin{array}{l}\text { Unweighted } \\
\text { gini index } \\
(\mathrm{Gu})\end{array}$ & $\begin{array}{l}\text { Weighted } \\
\text { gini index } \\
(\mathrm{Gw})\end{array}$ & $\begin{array}{l}\text { Theil } \\
\text { index } \\
(\mathrm{T})\end{array}$ \\
\hline 1990 & 11.625 & 0.668 & 0.537 & 0.346 & 0.257 & 0.239 & 0.106 \\
\hline 1991 & 14.473 & 0.781 & 0.665 & 0.389 & 0.282 & 0.273 & 0.152 \\
\hline 1992 & 21.881 & 1.062 & 0.854 & 0.448 & 0.318 & 0.304 & 0.214 \\
\hline 1993 & 23.082 & 1.058 & 0.862 & 0.471 & 0.327 & 0.315 & 0.223 \\
\hline 1994 & 24.079 & 1.053 & 0.890 & 0.502 & 0.336 & 0.332 & 0.244 \\
\hline 1995 & 23.915 & 1.057 & 0.889 & 0.510 & 0.335 & 0.334 & 0.246 \\
\hline 1996 & 27.723 & 1.047 & 0.967 & 0.580 & 0.366 & 0.400 & 0.290 \\
\hline 1997 & 24.746 & 1.067 & 0.996 & 0.596 & 0.372 & 0.410 & 0.306 \\
\hline
\end{tabular}

Figure A16: Regional olisparity trends in Vieînam

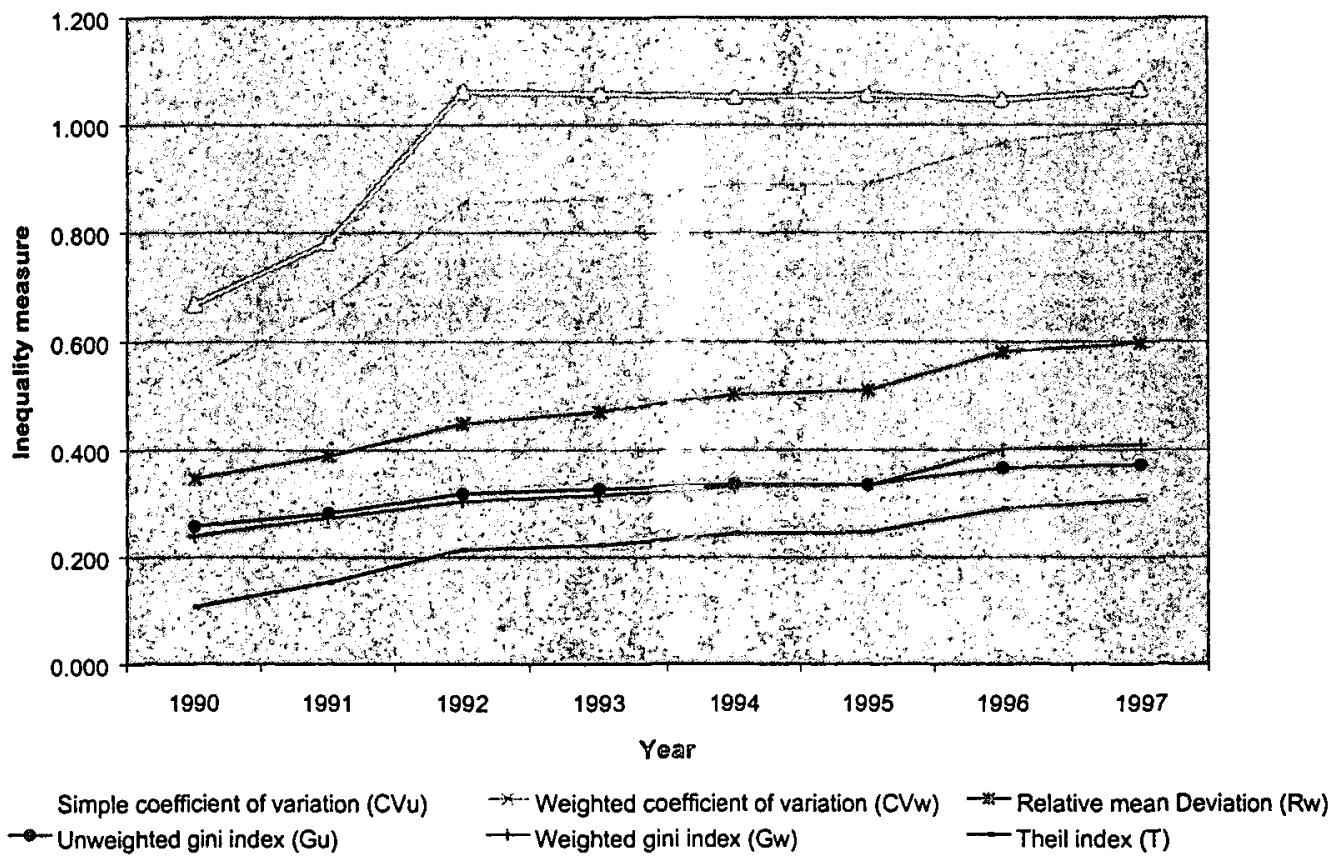




\section{References}

Akita, Takahiro and Lukman, Rizal Affandi, "Interregional Inequalities in Indonesia: A Sectoral Decomposition Analysis for 1975-92," Bulletin of Indonesian Economic Studies, Vol. 31, No. 2, August 1995, p.61-81

Asra, Abuzar, "Inequality Trends in Indonesia", Bulletin of Indonesian Economic Studles, Vol. 25, No. 2, August 1989

Atkinson, Anthony B., and Bourguignon, François, eds., Handbook of Income Distribution, Volume 1, Elsevier Science B. V., Amsterdam, Netherlands, 2000

Bajpai, Nirupam and Sachs, Jeffrey D., "Trends in Inter-State Inequalities of Income in India," Development Discussion Paper N. 528, Harvard Institute for International Development, May 1996

Barrow, R. J. and Sala-i-Martin, Economic Growth. New York: McGraw-Hill, 1995.

Boldrin, Michelle . Inequality and Convergence: Reconsidering European Regional Policies. Processed, April 2000.

Cashin, Paul and Sahay, Ratna, "Regional Economic Growth and Convergence in India," Finance \& Development, March 1996

Das, Sandwip Kumar and Barua, Alokesh, "Regional inequalities, economic growth and liberalisation: A study of the Indian economy," The Journal of Development Studies, London, Feb 1996

Decressin, Jörg, "Regional Income Redistribution and Risk Sharing: How Does Italy Compare in Europe?," IMF Working Paper WP/99/123, International Monetary Fund, Washington D. C., September 1999

Dev, S. Mahendra, "Economic Reforms, Poverty, Income Distribution and Employment," Economic and Political Weekly, March 4, 2000

Dev, S. M., Parikh, K. S., and Suryanarayana, M. H., "Rural Poverty in India: Incidence, Issues and Policies," Discussion Paper No. 55, Indira Gandhi Institute of Development Studies, Bombay

Garcia, Jorge Garcia and Soelistianingsih, Lana, "Why Do Differences in Provincial Incomes Persist in Indonesia?," Bulletin of Indonesian Economic Studies, Vol. 34, No. 1, April 1998, p. $95-120$

Giugale, Marcelo M., Nguyen, Vinh, Rojas, Fernando and Webb, Steven B. "Overview", Achievements and Challenges of Fiscal Decentralization - Lessons from Mexico, ed. Giugale, Marcelo M. and Webb, Steven B., The World Bank, 2000

Jian, Tianlun, Sachs, Jeffrey and Warner, Andrew M., "Trends in Regional Inequality in China," Working Paper 5412, National Bureau of Economic Research, 1996

Jha, Raghbendra, "Growth, Inequality and Poverty in India - Spatial and Temporal Characteristics," Economic and Political Weekly, March 11, 2000

Kakwani, Nanak C., Inequality and Poverty - Methods of Estimation and Policy Applications, The World Bank, Oxford University Press, 1980 
Kakwani, Nanak C., Large Sample Distribution of Several Inequality Measures - With Application to Côte d'Ivore, The World Bank, Washington D.C., 1990

Krugman, P. (1991). "Increasing Returns and Economic Geography", Journal of Political Economy 99, 483-499.

Kurian, NJ, "Widening Regional Disparities in India," Economic and Political Weekly, February 12,2000

Lyons, Thomas P., "Interprovincial Disparities in China: Output and Consumption, 1952-87," Economic Development and Cultural Change, 1991, p.471-506

Nagaraj, R., Varoudakis, A., and Veganzones, M. A., "Long Run Growth Trends and Convergence across Indian States," Journal of International Development, Vol. 12, 2000 p.45-70

Raiser, Martin, "Subsidizing inequality: Economic reforms, fiscal transfers and convergence across Chinese provinces," The journal of Development Studies, Vol. 34, No. 3, Feb. 1998, p.126

Rao, M. Govinda, Shand, R. T., Kalirajan, K. P., "Convergence of Income across Indian States," Economic and Political Weekly, March 27, 1999

Romer, P. (1990). “Endogenous Technical Change”, Journal of Political Economy 98, S71-S102.

Sacks, Michael Paul, "Regional Inequality and Branch Employment in Russia Between 1990 and 1995," Post-Communist Economies, Vol. 11, No. 2, 1999, p.149-159

Shah, Anwar and Raja Shankar (forthcoming). Regional Development Policies: Helping regions or building transfer dependencies? World Bank, Washington, D.C.

Shah, Anwar (2000). Federalism and Regional Equity: Building Partnerships or Transfer Dependencies. Paper Presented at the International Conference on Federalism Organized by the Forum of Federations, Brasilia, Brazil, May, 2000.

Shah, Anwar (1994). The Reform of Intergovernmental Fiscal Relations in Developing and Emerging Market Economies. Policy and Research Series No.23, World Bank: Washington, DC

Theil, Henri, Economics and Information Theory, North-Holland Publishing Company, Amsterdam, Netherlands, 1967

Tsui, Kai-yuen, "Economic reform and interprovincial inequalities in China," Journal of Development Economics, Vol. 50, 1996, p.353-368

Yagci, F., "Narrowing Inter-State Disparities Agenda for Fiscal and Sector Reforms," The World Bank, 1999

Williamson, Jeffrey G., "Regional Inequality and Process of National Development: A Description of the Patterns," Economic Development and Cultural Change, Vol. XIII, No. 4, Part II, July 1965, p.2-84

World Bank, India - 1997 Economic Update: Sustaining Rapid Growth, Report No. 16506-IN, May 30, 1997

Yao, Shujie and Liu, Jirui, "Economic reforms and regional segmentation in rural China," Regional Studies, Vol. 32, No. 8, Cambridge, November 1998, p. 735-746 


\section{Notes}

\footnotetext{
${ }^{1}$ This number includes both the former West Germany and unified Germany.

${ }^{2}$ Some examples include Williamson (1965), Dev (2000), Nagaraj, Varoudakis and Veganzones (2000), Decressin (1999), Lyons (1991), Raiser (1998), Tsui (1996), Akita and Lukman (1995) and Sacks (1999)

${ }^{3}$ Bajpai and Sachs (1996), Cashin and Sahay (1996), Jian, Sachs and Warner (1996), and Garcia and Soelistianingsih (1998)

${ }^{4}$ Tsui (1996) and Yao and Liu (1998)

${ }^{5}$ All the countries in our sample, except Uganda, Nepal and Poland were used in the regression analysis. We could not obtain data to calculate the weighted measures of inequality for these countries.

${ }^{6}$ The countries included are the United States, Canada, India, West Germany, Brazil, Mexico, Spain, Russia. Italy, France, Chile, United Kingdom, Thailand, Romania and Indonesia.

'This is consistent with Williamson's (1965) "inverted U" thesis that inequalities widen in the early development stages, while mature development produces divergence.

${ }^{8}$ Data and information taken from the EIU's Philippines Country Profile.

${ }^{9}$ Data and information taken from the EIU's Thailand Country Profile.

${ }^{10}$ Shah and Shankar (forthcoming) delve deeper into the design of such policies and their impacts.
} 




\section{Policy Research Working Paper Series}

Title

WPS2693 Helping People Help Themselves: Toward a Theory of Autonomy-

Compatible Help
WPS2694 Financial Development and Financing Constraints: International Evidence

from the Structural Investment Model

WPS2695 Trade, Credit, Financial Intermediary Development, and Industry Growth

WPS2696 Firms as Financial Intermediaries: Evidence from Trade Credit Data

WPS2697 Regional Integration and Industrial Growth among Developing Countries: The Case of Three ASEAN Members

WPS2698 Foreign Bank Entry: Experience, Implications for Developing Countries, and Agenda for Further Research

WPS2699 Benefits and Costs of International Pierre-Richard Agénor Financial Integration: Theory and Facts

WPS2700 Business Cycles, Economic Crises, Pierre-Richard Agénor and the Poor: Testing for Asymmetric Effects

WPS2701 Trade and Production, 1976-99

WPS2702 Productivity versus Endowments: A Study of Singapore's Sectoral Growth, 1974-92

WPS2703 Integrating Independent Power Producers into Emerging Wholesale Power Markets

WPS2704 Regulatory Governance and Chile's 1998-99 Electricity Shortage

WPS2705 Concession Contract Renegotiations: Some Efficiency versus Equity Dilemmas Alexander Galetovic
Author

David Ellerman

George Clarke

Asli Demirgüç-Kunt

Vojislav Maksimovic

Dorsati H. Madani

Raymond Fisman

Inessa Love

Date

October 2001

October 2001

October 2001

October 2001

October 2001

October 2001

Maria Soledad Martinez Peria

Susana M. Sánchez

Contact for paper

B. Mekuria 82756

K. Labrie 31001

K. Labrie 31001

K. Labrie 31001

L. Tabada 36896

P. Sintim-Aboagye 38526

M. Gosiengfiao 33363

October 2001

M. Gosiengfiao 33363

November 2001

L. Tabada 36896 Marcelo Olarreaga

November 2001

L. Tabada 36896

Fiona Woolf

November 2001

Energy Help Desk 30652

Ronald Fischer

November 2001

G. Chenet-Smith 36370

November 2001

G. Chenet-Smith 36370 


\section{Policy Research Working Paper Series}

Title

WPS2706 Household Income Dynamics in Rural China

WPS2707 Financial Intermediary Development and Growth Volatility: Do Intermediaries Dampen or Magnify Shocks?

WPS2708 Accountability and Corruption: Political Institutions Matter

WPS2709 Explaining Leakage of Public Funds

WPS2710 Breaking up the Collective Farm: Welfare Outcomes of Vietnam's Massive Land Privatization

WPS2711 Identifying Class Size Effects in Developing Countries: Evidence from Rural Schools in Bolivia

WPS2712 Contract Risks and Credit Spread Determinants in the International Project Bond Market

WPS2713 Causes of Inequality in Health: Who You Are? Where You Live? Or Who Your Parents Were?

WPS2714 On Decomposing the Causes of Health Sector Inequalities with an Application to Malnutrition Inequalities Naoko Watanabe in Vietnam

WPS2715 Paying for Health Care: Quantifying Fairness, Catastrophe, and Impoverishment, with Applications to Vietnam, 1993-98

WPS2716 Does Foreign Bank Penetration Reduce Access to Credit in Developing Countries? Evidence from Asking Borrowers

\section{Author}

Jyotsna Jalan

Martin Ravallion

Thorsten Beck

Mattias Lundberg

Giovanni Majnoni

Daniel Lederman

Norman Loayza

Rodrigo Reis Soares

Ritva Reinikka

Jakob Svensson

Martin Ravallion

Dominique van de Walle

Miguel Urquiola

Mansoor Dailami

Robert Hauswald

Adam Wagstaff

Pierella Paci

Heather Joshi

Adam Wagstaff

Eddy van Doorslaer

Adam Wagstaff

Eddy van Doorslaer

\section{Date}

November 2001

November 2001

November 2001

P. Soto

37892

November 2001

November 2001

November 2001

November 2001

November 2001

H. Sladovich 37698

November 2001

H. Sladovich 37698

November 2001

November 2001

H. Sladovich 37698

C. Cunanan 32301

H. Sladovich 37698

W. Nedrow 31585
George R. G. Clarke Robert Cull Maria Soledad Martinez Peria
H. Sladovich 37698

P. Sintim-Aboagye 37644 